NBER WORKING PAPER SERIES

\title{
CEO-BOARD DYNAMICS
}

John R. Graham

Hyunseob Kim

Mark T. Leary

Working Paper 26004

http://www.nber.org/papers/w26004

\author{
NATIONAL BUREAU OF ECONOMIC RESEARCH \\ 1050 Massachusetts Avenue \\ Cambridge, MA 02138 \\ June 2019
}

We appreciate comments from Ofer Eldar, Yaniv Grinstein (Drexel discussant), Byoung-Hyoun Hwang, Dirk Jenter (AFA discussant), Andrew Karolyi, Stephen Karolyi, Peter Limbach, Roni Michaely, Felipe Varas, Neng Wang, Toni Whited, and seminar and conference participants at the AFA Annual Meetings, Binghamton University, Columbia University, Cornell University, Drexel Corporate Governance Conference, Duke University, Federal Reserve Bank of Richmond (Charlotte), IDC Summer Finance Conference, Stanford University, Tuck, Purdue University, Rome Junior Finance Conference (EIEF), the SEC, SMU, University of Iowa, University of Kentucky, University of Notre Dame, University of Rochester, USC, University of Utah, Vanderbilt University, Washington University in St. Louis, the WSJ CEO Forum, and Yale Law School, excellent research assistance from Penghao Chen, Hyungjin Choi, David Hong, Dawoon Kim, Jason Lee, Boyao Li, Song Ma, Pradeep Muthukrishnan, Youngjun Song, Curtis Wang, Daniel Woo, Hyun Gu Yeo, Gang Zhang, and data support from the librarians at Cornell, Duke, Harvard, and MIT. We thank William Goetzmann for sharing data on historical stock prices and Charlie Hadlock, Jesus Salas, and Timothy Quigley for sharing data on CEO deaths. This paper was previously titled "CEO Power and Board Dynamics". The views expressed herein are those of the authors and do not necessarily reflect the views of the National Bureau of Economic Research.

NBER working papers are circulated for discussion and comment purposes. They have not been peer-reviewed or been subject to the review by the NBER Board of Directors that accompanies official NBER publications.

(C) 2019 by John R. Graham, Hyunseob Kim, and Mark T. Leary. All rights reserved. Short sections of text, not to exceed two paragraphs, may be quoted without explicit permission provided that full credit, including ( $)$ notice, is given to the source. 
CEO-Board Dynamics

John R. Graham, Hyunseob Kim, and Mark T. Leary

NBER Working Paper No. 26004

June 2019

JEL No. B26,G3,J3,M12

\begin{abstract}
$\underline{\text { ABSTRACT }}$
We examine CEO-board dynamics using a new panel dataset that spans 1920 to 2011. The long sample allows us to perform within-firm and within-CEO tests over a long horizon, many for the first time in the governance literature. Consistent with theories of bargaining or dynamic contracting, we find board independence increases at CEO turnover and falls with CEO tenure, with the decline stronger following superior performance. CEOs are also more likely to be appointed board chair as tenure increases, and we find evidence consistent with a substitution between board independence and chair duality. Other results suggest that these classes of models fail to capture important elements of board dynamics. First, the magnitude of the CEO tenure effect is economically small, much smaller for example than the strong persistence in board structure that we document. Second, when external CEOs are hired, board independence falls and subsequently increases. Third, event studies document a positive market reaction when powerful CEOs die in office, consistent with powerful CEOs becoming entrenched.
\end{abstract}

John R. Graham

Duke University

Fuqua School of Business

100 Fuqua Drive

Durham, NC 27708-0120

and NBER

john.graham@duke.edu
Mark T. Leary

Olin Business School

Washington University in St. Louis

Campus Box 1133, One Brookings Drive

St. Louis, MO 63130

and NBER

leary@wustl.edu

Hyunseob Kim

Cornell University

Johnson Graduate School of Management

321 Sage Hall

114 East Avenue

Ithaca, NY 14853

hk722@cornell.edu

A data appendix is available at http://www.nber.org/data-appendix/w26004 


\section{Introduction}

In recent years, regulators and investors have shown increasing interest in the composition of corporate boards of directors. ${ }^{1}$ Academic research suggests there is no universally optimal board composition. While prior empirical research has focused largely on how board structure varies in the cross-section with characteristics of the firm or CEO, theory suggests that boards may also optimally change dynamically within the tenure of a CEO. For example, while a key role of the board is overseeing and monitoring managers, excessive monitoring may impose costs on the firm, or over-constrain management. These tradeoffs are likely to evolve through time as more is known about the ability of the CEO and the scope for agency conflicts changes. As a result, a firm might optimally shift to a board structure that supports more or less intensive monitoring over time. In this paper, we use a unique longitudinal dataset to study within-firm dynamics of corporate boards and how they relate to the tenure, turnover and performance of the CEO.

We organize our paper around the rich set of predictions emanating from bargaining and dynamic agency models. In bargaining models, CEOs negotiate with the board over compensation and private benefits of control (e.g., Hermalin and Weisbach, 1998; HW). Successful CEOs gain bargaining power as their perceived ability (or match quality) and tenure increase. Among other things, successful CEOs negotiate for less monitoring, which is also optimal from the board's perspective. A similar outcome can occur in dynamic contracting models (e.g., DeMarzo and Fishman, 2007a, b). ${ }^{2}$ As a CEO performs well over time, both compensation and continuation value (i.e., the CEO’s “stake” in the firm) increase, which reduces agency problems and the need

\footnotetext{
${ }^{1}$ For example, in the early 2000s the NYSE and NASDAQ implemented listing requirements that boards be majority independent; more recently, activist investors often focus on board structure and composition.

${ }^{2}$ A partial list of dynamic contracting models includes Zwiebel (1996), DeMarzo and Sannikov (2006, 2017), Bolton et al. (2011), DeMarzo et al. (2012) and Piskorski and Westerfield (2016). Below we also interpret some results in the context of the agency rent extraction arguments of Bebchuk et al. (2002) and Bebchuk and Fried (2003).
} 
for monitoring. Note that less intense monitoring could occur via lower board independence or by appointing the CEO board chair. In addition to less monitoring, successful CEOs are expected to be paid more and experience turnover that is less sensitive to performance. All of this occurs in a setting of endogenous, optimal governance in which the CEO's perceived ability or agency problems evolve dynamically. (The theory is described in more detail in Section 4.)

We note that some of these predictions are not unique to optimal contracting or bargaining models. For example, if CEOs have excess power over the board selection process, they may be able to implement an inefficiently weaker board over time (Bebchuk and Fried, 2004), which could result in a negative relation between CEO tenure and board independence. Thus, our objective is not to test predictions of specific models per se, but rather to document the within-firm (and often within-CEO) dynamics of board structures and discuss the extent to which these are consistent (or not) with different classes of models. We hope this both speaks to the empirical relevance of existing models and provides guidance for further development of governance theory.

It is important to highlight that these theories make dynamic predictions about board structure, which by nature occur within the tenure of a CEO at a given firm. Yet due to data limitations, prior empirical tests have largely been conducted using repeated cross-sections. Thus, Adams, Hermalin, and Weisbach (2010, p. 69) emphasize the need for studies that "shed more direct empirical light on the dynamic nature of the CEO-board relationship within-firms" (emphasis added). Moreover, we note that some theoretical predictions are within-CEO. To conduct these dynamic tests, and especially to isolate within-CEO and within-firm effects from other dynamic outcomes, one needs a long time-series of data that includes multiple CEOs per firm. To achieve this, we construct a new officer and director database with about 87,000 firm- 
year observations from 1920 to 2011, allowing us to study board dynamics over many regulatory and economic environments, and within the careers of over 15,000 CEOs.

We begin our exploration of CEO-board dynamics by documenting that, on average, onethird of the board is replaced when a new CEO is appointed. Interestingly, even with this amount of director turnover, board composition is persistent in that exiting dependent (independent) directors are replaced with a very similar proportion of dependent (independent) directors. Using our long panel, we conduct rigorous tests of board persistence. We document that initial board independence is by far the strongest predictor of board independence decades later: firms that initially have independent (or dependent) boards on average still have relatively independent (dependent) director-dominated boards 30 years later. These findings contrast somewhat with the conclusions of Cicero et al. (2013, p.109), who argue that "firms frequently changed their board structures during the pre-SOX period.” They show that during 1991-2003, firms frequently adjusted the fraction of outside directors in a way that moved the independence ratio toward a predicted level (that changed with firm characteristics), although large changes were less common. ${ }^{3}$ While their evidence suggests firms act to adjust board structure in response to changing characteristics, we show that board independence is nonetheless quite persistent over long horizons.

While board structure is sticky, it is not fixed. Our near-century of data provides power to test whether the changes that do occur are consistent (or not) with theories of board structure and dynamic agency. To benchmark to the existing literature, we first perform regressions over the last 16 years of our sample using repeated cross-sections without firm fixed effects and find a negative

\footnotetext{
${ }^{3}$ Denis and Sarin (1999, p.189) also conclude, "substantial changes in ownership structure and board composition are not uncommon and are not transitory." Their conclusion is likely affected by their findings on board size and insider ownership, which they show change much more frequently than board independence. They report that independence ratios change by more than 0.2 in only $4 \%$ of firm-years, more in line with the persistence we document.
} 
relation between CEO tenure and board independence; ${ }^{4}$ however, we show that there is no withinfirm relation during this era when we include firm fixed effects. When we examine the full sample starting in 1920, though, we do find a within-firm negative relation between CEO tenure and board independence. Similarly, we also find a positive within-firm relation between CEO tenure and both the CEO being appointed board chair and compensation. Thus, ours is the first paper to document a negative relation between executive tenure and board monitoring intensity using within-firm tests. $^{5}$

The timing of the non-relation in modern data is notable because the NYSE and NASDAQ implemented regulations requiring listed firms to have majority independent boards after 2002, altering CEO-board dynamics. In our tests, we confirm that the negative within-firm relation between board independence and CEO tenure dissipates following the 2002 listing regulations. While the regulations increased board independence as intended, HW (p. 111) argue that "As long as the bargaining process [between the CEO and board] itself is unaffected by reforms, the equilibrium will be little affected.” Building on this logic, we argue that if regulation constrains boards to be more independent without changing the incentives of CEOs and directors, firms will reduce monitoring via other channels. Specifically, we explore whether regulations that increase board independence are associated with an increase in CEOs being appointed dual board chair, again within-firm. We find evidence consistent with this prediction: the within-firm relation between CEO tenure and the likelihood of the CEO being appointed board chair became more pronounced after the 2002 board independence regulations were implemented. Other tests show

\footnotetext{
${ }^{4}$ See, for example, Baker and Gompers (2003), Boone et al. (2007), and Dikolli et al. (2014).

${ }^{5}$ Using a sample of 142 firms from 1971-1983, Hermalin and Weisbach (1988) employ specifications both with and without firm fixed effects to examine the relation between CEO tenure and additions/departures of insider and outsider directors. However, their results with fixed effects are generally weaker than or inconsistent with those without fixed effects, which the authors attribute to limited within-firm variation in their sample.
} 
that the propensity to be appointed dual chair increases early in the typical CEO's career, while the decline in board independence happens later. This apparent substitution to dual chair is new to the literature and seems to be a fruitful area for future research.

The negative relation between CEO tenure and board independence holds both at the time of CEO turnover and within-CEO. That is, there are two sources of the negative CEO tenure-board independence relation. First, there is a jump in board independence at the time a new CEO is appointed. This makes sense because both uncertainty about the CEO's ability (and thus the need for stricter monitoring) and the change in CEO tenure (reduction in CEO bargaining power) are greatest at this moment. ${ }^{6}$ Second, board independence gradually declines over a CEO's tenure. We document heterogeneity in this dynamic relation that is directionally consistent with bargaining and dynamic agency theories. In particular, the decline in independence is stronger following strong corporate performance, which would increase the CEO's perceived ability and bargaining power.

In summary so far, we find that directionally (i.e., signs of estimated coefficients) the dynamics of board structure are consistent with dynamic bargaining and contracting theory: As their tenure increases, successful CEOs are more likely to serve as dual board chair, and interact with boards that grow less independent; and these relations vary conditional on performance. Consistent with these dynamics, we also find that CEOs’ pay increases with tenure and powerful CEOs are less likely to be replaced upon poor corporate performance.

However, we present five sets of results that are difficult to reconcile with extant bargaining and contracting models. First, the empirical magnitude of the negative relation between CEO tenure and board independence is small in absolute terms: Board independence on average

\footnotetext{
${ }^{6}$ Tenure drops from an average of six years for departing CEOs to one for incoming CEOs.
} 
decreases by $0.15 \%$ per year of CEO tenure. To put this magnitude in context, the average board in our sample has about 10 members. Thus, a shift of one independent director to dependent (a $10 \%$ change in independence ratio) is associated with about 70 years of additional tenure. Even at CEO turnover, the independence ratio increases by only $0.6 \%$ on average, consistent with roughly one in seventeen firms replacing one dependent director with an independent director. The CEO tenure-board independence relation is also small in relative magnitude, compared to other forces such as those generating the strong persistence we document. ${ }^{7}$ Further, the within-firm relation does not hold once we remove year fixed effects. This latter finding suggests that on average the tenure-independence relation is also small relative to secular time trends in board structure.

Second, opposite in direction to our main finding, board independence decreases when outside CEOs are appointed and subsequently increases over time. We argue below that this may be because outside appointees benefit from the advice of internal directors - but this suggests that, at least for this subset of firms, bargaining or contracting mechanisms are dominated by concerns over the advisory role of the board. Third, as mentioned above, we do not find a negative independence-tenure relation after 2002. While we do find evidence consistent with a post-2002 substitution towards dual board chairs, this trade-off is not explicitly modeled in existing theory. Fourth, we present evidence below that succession planning may play a role in the jump in board independence at the time of CEO turnover. Succession tournaments have been explored in previous research (e.g., Hermalin and Weisbach, 1988) and at least partially crowd out bargaining and dynamic contracting explanations.

Fifth, we explore how the market reacts when powerful CEOs depart their firms. Because of endogeneity concerns, we examine this issue on a sample of turnover events tied to the CEO's

\footnotetext{
${ }^{7} \mathrm{HW}$ argue that optimal bargaining in their framework can generate persistence in board structures, but they do not model formally nor explore magnitudes.
} 
(sudden) death. ${ }^{8}$ We find that the announcement of the departure of a powerful CEO (relatively long job tenure, dual board chair, or founder of the firm) is associated with about a $3 \%$ higher abnormal return, relative to departures of less powerful CEOs. This finding is somewhat surprising because in bargaining models, CEO power emanates from perceived superior ability (or match quality) relative to a replacement. Instead, our results seem more consistent with ex-post entrenchment resulting from a weaker board, or of a weak board resulting from an entrenched CEO’s control over the governance process (Bebchuk and Fried, 2004).

We thus conclude that learning and contracting between the board and CEO are relevant, but are not empirically dominant forces behind the evolution of corporate boards. Other factors, including the advisory role of the board, persistence, and the CEO's excess power over the nominating process, are likely to be important and should be a focus of future theoretical and empirical work.

While earlier studies have explored elements of board dynamics and the interaction between CEOs and board structure, ours is the first to study these dynamics strictly within-firm and within-CEO, using a comprehensive panel of data covering thousands of firms and over 90 years. This has several important advantages. First, while prior empirical studies of board dynamics and CEO-board bargaining rely primarily on small samples or short time horizons, our long panel covering multiple CEOs per firm provides sufficient power to estimate within-firm and within-CEO dynamics. Second, reliably detecting the degree of persistence in board structure requires studying a long database like the one we use. Third, our long time series enables us to document long-term trends in board structure and CEO turnover. ${ }^{9}$ Fourth, we are able to examine

\footnotetext{
${ }^{8}$ See also Fee, Hadlock, and Pierce (2013), Quigley, Crossland, and Campbell (2017) and Jenter, Matveyev, and Roth (2019).

${ }^{9}$ Lehn et al. (2009) also study average board structure over a long horizon, but use a survivorship sample including only 82 of the largest firms. We find substantially different trends using our more comprehensive sample.
} 
numerous board structure relationships on a consistent set of firms, versus the extant empirical evidence based on a collection of studies, each of which typically focuses on a subset of issues, and studies different time periods and samples of firms. We also examine how these relations have changed over time, for example, before and after the governance reforms of the early 2000s.

\section{Sample construction and long-term trends}

\subsection{Data on corporate boards of directors and officers}

We construct a comprehensive database of corporate officers and directors, such as the Chief Executive Officer (CEO), Chief Financial Officer (CFO), ${ }^{10}$ various corporate vice presidents, and others, at public U.S. companies from 1920 to 2011. We combine information from a number of sources. First, we hand-collect names of corporate officers and directors, as well as financial data on their firms, from Moody’s Industrial Manuals ('Moody’s’) from 1920 to 1992, and also the year $1998 .{ }^{11}$ Second, we collect names of corporate directors and officers from Compact Disclosure during 1985-2005. Compact Disclosure derives information from firms’ public disclosure such as 10-Ks, 10-Qs, and Proxy Statements. Third, we supplement these two primary board and officer databases using Mergent (which took over the Industrial Manual from Moody’s; 2002-2009) and Board Analyst (2005-2011) for more recent years. ${ }^{12}$ We gather stock price and return data from CRSP and financial statement data from Compustat or Moody's

\footnotetext{
${ }^{10}$ The 'CEO' includes corporate officers with various titles depending on the era, including 'President' and 'Chief Executive Officer'. The 'CFO' is the finance chief and includes corporate officers in various titles depending on the era, including 'Treasurer' and 'Chief Financial Officer'.

${ }^{11}$ See Graham, Leary, and Roberts (2015) for a description of coverage and available financial statement information in Moody's. Papers that analyze smaller samples of Moody's financial and board information include Lehn et al. (2009), Frydman, Hilt, and Zhou (2015) and Avedian, Cronqvist, and Weidenmier (2015).

${ }^{12}$ We drop 795 observations from Board Analyst because they have information only for the CEO but not the other officers. However, if we include these observations the results are very similar to those in the paper. In addition, if we drop all Board Analyst data in the sample, the results also remain similar.
} 
Industrial Manuals (for firm-years not covered by Compustat). ${ }^{13}$ Like most corporate finance research, we do not include firms in the financial (SIC 6000-6999), transportation (4000-4599), and utility (4900-4999) sectors.

To maintain comparability across the various databases and years, we focus on U.S. firms listed on the NYSE or AMEX..${ }^{14}$ Our main results are similar if we include ADRs and NASDAQ firms, or if we use NYSE firms only (see Appendix Table 1, Panel D). We have CEO and board information for nearly $80 \%$ of the NYSE/AMEX firms in the CRSP database over the 1920-2011 period. ${ }^{15}$ All total, our database contains 86,946 firm-year observations and more than 8,500 CEO turnover events.

\subsection{Descriptive statistics}

Table 1 presents descriptive statistics on firm-year observations in the full database and by decade. CEO turnover averages $11.9 \%$ per year for the full sample, increasing from the first to the second half of the sample. The average CEO, CFO, and board chair tenures are 6.3, 5.1, and 5.9 years, respectively. The CEO holds the title of board chair ('CEO-Chair duality') for $41.6 \%$ of observations, with substantial time-series variation over the century. The average board in our sample has about 10 directors (including the chair) and boards have gotten somewhat smaller over the past century. The ratio of the number of outside directors (i.e., directors who are not current officers of the firm) to the total number of directors is 0.64 , and the proportion of independent directors (i.e., directors who are (i) neither current nor previous officers of the firm, nor (ii) family

\footnotetext{
${ }^{13}$ We obtain stock price data from 1920 to 1925 from William Goetzmann.

${ }^{14}$ We identify and delete non-U.S. firms (i.e., ADRs) using the approach in Marosi and Massoud (2008).

${ }^{15}$ See Appendix C (and Appendix Table 4) for descriptions of the characteristics of the firms in the "missing 20\%" of the sample.
} 
members of the CEO, proxied by having the same last name) is $0.58 .{ }^{16}$ Both ratios were stable until the 1980s, then increased in recent decades.

Panel B presents descriptive statistics on firm-level financial data (exclusively from Moody's before 1951; mostly from Compustat starting in 1951, though we fix the Compustat backfill problem during 1951-1962). The average firm has $\$ 2.29$ billion of real book assets in 2000 constant dollars (CPI-adjusted) and has been in the sample about 21 years ("firm age"). Other characteristics are generally similar to those in modern Compustat analysis. Notably, some of these firm characteristics (such as tangibility, ROA, and Tobin’s q) changed over the century.

\subsection{Long-term trends in CEO turnover, CEO appointment, and board structure}

Fig. 1 presents the long-term evolution of various U.S. CEO and board trends. The figure also presents (in red dashed lines) trends in residuals of these variables after controlling for firm characteristics (which are listed in the caption to Fig. 1). Panel A shows that three-year moving average CEO turnover rates for NYSE and AMEX firms were relatively low from 1922 to 1950 before increasing in the middle portion of the sample (1950-1970), then decreasing starting around 1970. The rate of CEO turnover for the later period is comparable with those documented in Kaplan and Minton (2012), who find an average 15.8\% turnover rate from 1992 to 2007. In addition, we find a negative $(-34.0 \%, t$-stat $=-3.39)$ time-series correlation between average CEO turnover rates and ROA, suggesting that CEO turnover is counter-cyclical.

Panel B shows three-year moving averages of the fraction of "outside CEO” (i.e., neither a current nor previous officer of the firm) appointments from 1933 to 2011. We exclude years prior to 1933 to allow a start-up period to accumulate information on previous corporate officers. The frequency of outside CEO appointments declined from the 1930s to the 1940s, then stabilized until

\footnotetext{
${ }^{16}$ We do not consider whether a director has business relations with the firm (e.g., lawyers and bankers), given that Moody's and Compact Disclosure do not provide such information on directors.
} 
the 1970s. Beginning in the late 1980s, outside CEOs became increasingly common, reaching around $44 \%$ by the late-1990s. This upward trend from the 1970s to the 1990s is consistent with evidence in Huson, Parrino, and Starks (2001) and Murphy and Zabojnik (2007); the latter argue that the trend reflects a shift in the importance of managerial skills for CEOs from firm-specific knowledge to general (or portable) managerial ability, such as MBA education. Our evidence from the long time-series highlights this recent trend by placing it in the context of a much longer horizon and highlights that external hires were also common in the 1930s and 1960s. Graphs adjusted for firm characteristics show similar trends for the CEO turnover rate and the fraction of outside CEO appointments.

Panel C presents the ratio of the number of independent directors to the total number of directors from 1933 to 2011. Board independence was stable at about 50\% for four decades starting in the 1930s; the cross-sectional standard deviation (not in graph) was also very steady at about 19\% over these four decades. From the late-1970s to mid-1990s, average board independence increased to around 60\%. Following imposition of the 2003 NYSE and NASDAQ amendments that require majority independent boards (and 2002's Sarbanes-Oxley), ${ }^{17}$ average board independence increased to 74\% by 2011 (and the post-2003 standard deviation declined below 13\%). The red dashed line shows a similarly increasing trend post-1970s, although the magnitude of the increase is somewhat muted when firm characteristics are controlled. We later examine whether this mandated increase in board independence affects other dynamic outcomes between the CEO and board.

Panel D presents the proportion of firms that have CEOs who are also board chairs from 1920 to 2011. The titles of the CEO and chair were largely separate before the 1960s, at which

\footnotetext{
${ }^{17}$ SOX was signed into law in July 2002 and the SEC approved the NYSE and NASDAQ's new corporate governance requirements in November 2003. See Chhaochharia and Grinstein (2007) for a detailed timeline.
} 
time the frequency of the dual title increased to a peak of $73 \%$ in the mid-1980s. ${ }^{18}$ Shortly thereafter, duality began to decrease (which is also apparent when firm characteristics are controlled for in the red dashed line), possibly due to "governance activists" such as the National Association of Corporate Directors (NACD) which supported separating the two roles (see, e.g., Wangler, 1994; NACD, 1996). The downward trend is also consistent with Dahya, McConnell, and Travlos (2002) who show that the duality of the titles began to disappear in the U.K. in 1992 when the Cadbury Committee recommended separation of chair and CEO titles.

\section{Persistence of board structure}

Fig. 1, Panel C suggests that board independence is slow-moving at the aggregate level. In this section, we examine the extent to which this is true at the firm level and if so, whether it occurs because directors rarely change or whether director rotation occurs in ways that keep board structure stable. We first document changes in board members in the years of and following CEO turnover. In Table 2, we sort observations in event time, where year 0 is the year of a change in CEO, and report the average additions and departures of independent and dependent directors in each year. Panels A and B show these turnovers for internal and external CEOs, respectively. In both panels, addition and departure rates increase in the year of CEO turnover, then revert to relatively stable rates. When a new internal CEO is appointed (Panel A), on average 0.98 new independent directors join the board and 0.95 leave, a bit higher than the average addition (departure) rate of $0.86(0.79)$ in non-CEO-turnover years. The increase in board turnover is more

\footnotetext{
${ }^{18}$ The dual chair analysis does not include the one-fifth of the observations for which the chair title is not clearly denoted in data sources (such as Moody's). If we include these observations under the assumption that the CEO is always chair, the hump-shaped trend is similar to that in Panel D from 1950 onward, also peaking in the mid-1980s. Also, the conclusions we draw below based on our dual chair regression analyses are unchanged whether or not we exclude the ambiguous observations.
} 
pronounced for dependent directors. On average, 2.6 dependent directors leave the board in the year of CEO change and 2.46 dependent directors are added. While in most cases one of the 2.6 (2.46) is the outgoing (incoming) CEO, this still represents a meaningful level of board turnover relative to the average board size of about 10 members.

Even though roughly 35\% of the board turns over in the year of CEO turnover (see also Cicero et al., 2013), because the addition rates are similar to the departure rates, the independence ratio changes little, leading to slow-moving board structure. The movement we do see in year 0 in Panel A, though, is toward more independence. In the years following CEO turnover, the addition and departure rates are similar to each other within a given type of director, with the rates generally declining slightly over the CEO’s tenure.

Panel B shows that for external CEO appointments the addition and departure rates are also similar to each other within each of the independent and dependent director categories, and decrease over the CEO's tenure, again suggesting slow-moving board structure. One difference, though, is that in year 0 when an external CEO is appointed, more independent directors leave and dependent directors are added on net. This is consistent with the importance of an advisory role for internal directors when an external CEO is appointed (see Section 4.6 for additional analysis of board dynamics for external CEOs).

We now more formally explore board persistence after netting the effects of director rotation. Though they do not formally model persistence, Hermalin and Weisbach (1998) argue that in their framework one might expect hysteresis in board structure: "Strong, independent boards will beget stronger, more independent boards than will weak boards” (p.107). Alternatively, even if there are few frictions in the adjustment of board structure, we would expect these structures to be stable over time if their determinants change slowly. 
First, in each calendar year, we sort all firms into four equal-sized groups based on their board independence ratios, and compute the groups' average independence ratios for the next 30 years. We repeat this process for all calendar years from 1920 to 1992 and then average across the calendar years. Fig. 2 shows that while there is some convergence, differences in board independence ratios on average persist over 30 years. For comparison, we note that the patterns we document here for board independence are similar to those documented for corporate leverage by Lemmon, Roberts, and Zender (2008), both in terms of the dispersion of initial ratios and the degree of convergence over the subsequent 20 years.

Second, we follow Lemmon et al.’s (2008) capital structure analysis and test whether initial board independence is a significant determinant of future independence by estimating the following equation:

Independence $_{i t}=\alpha_{t}+\beta_{1}$ Independence $_{i 0}+\beta_{2}$ CEO tenure tit $_{i t}+X_{i t}{ }^{\prime} \gamma+\varepsilon_{i t}$,

where Independence it is defined as the ratio of the number of independent directors to total directors; $\alpha_{t}$ represents year fixed effects; Independence $i 0$ is the first observed board independence ratio for firm $i$; $C E O$ tenure $_{i t}$ is the number of years for which the CEO has been chief executive in firm $i$ as of year $t$; and $X_{i t}$ represents a vector of firm-level control variables including firm age, log board size, log book assets, Tobin’s q, two-digit SIC industry-adjusted return on assets (ROA), and asset tangibility; and $\varepsilon_{i t}$ represents random errors clustered at the firm level. Our choice of firm-level controls is motivated by prior studies that show board structure is correlated with characteristics proxying for the scope and complexity of operations, information asymmetry, or potential for agency conflicts (e.g., Boone et al., 2007; Coles, Daniel, and Naveen 2008; Lehn et al., 2009). 
Table 3, Panels A and B use, respectively, the full sample (excluding the first year for each firm) and subsamples consisting of the cross-section of firms that survive five, 10, and 20 years. Panel C repeats the analysis from Panel B in regressions that include initial board independence as the only independent variable. To facilitate comparisons across variables, in this table only we scale each independent variable by its standard deviation. Thus, each coefficient estimate represents the change in board independence (in percentage points) corresponding to a onestandard deviation (SD) change in an independent variable. In all three panels, the coefficient on initial independence is positive and highly significant (at better than a $1 \%$ level). In fact, its statistical and economic significance is substantially higher than that of any of the other variables included in Panel A. In terms of economic magnitude, column 3 of Panel A, which controls for firm-level characteristics, shows that a one-SD increase in the initial independence (19.6 percentage points) is associated with an 8.1 percentage point increase in board independence. In addition, the $\mathrm{R}^{2}$ s s in Panel C show that initial board independence explains 32.1\% (15.9\%) of the variation in board independence 10 (20) years later.

Persistence is also evident in Table 3, Panel D, which shows the probability of transition from one quartile of board independence to another. In each year, we sort firms into quartiles based on board independence and follow them for ten years. Board independence is most persistent in the two extreme quartiles. For example, $82.5 \%$ of firms in the lowest quartile in year 0 are still in the quartile the following year; and the probability of remaining in this same quartile is $58.3 \%$ ten years after the initial sorting. Similarly, $77.7 \%(45.8 \%)$ of firms in the highest quartile in year 0 remain in the same quartile one year (10 years) later. We note that these transition probabilities are similar to those documented by DeAngelo and Roll (2015) for leverage. For example, after 10 years, we find that the probabilities of being in the initial quartile of board independence are 58.3\%, 
$33.5 \%, 33.0 \%$, and $45.8 \%$, respectively, for quartiles 1 through 4 . The same probabilities reported by DeAngelo and Roll (2015) are 52.9\%, 33.2\%, 34.4\%, and 50.7\%.

While persistence is evident, it is not complete. Panel E shows results from regressing board independence on firm and year fixed effects. Firm effects that are constant for the entire time a firm exists in our sample explain 57\% of the variation in independence over the centurylong panel. Allowing firm effects to change every three decades (e.g., two FEs for a firm that exists between 31 and 60 years in our sample), or including firm-decade FEs, increases the $\mathrm{R}^{2}$ to $71 \%$ and $82 \%$, respectively. Thus, over a long enough horizon, there are significant changes in board structure within the life of a given firm.

Overall, our descriptive evidence on changes in board composition reveals four main findings. First, there is substantial turnover of board members, especially when there is a change in CEO. Second, changes in board structure, as measured by the independence ratio, are modest relative to the changes in individual board members. Third, as a result, board structure is fairly persistent, of a degree comparable to that of corporate leverage. The causes of board persistence are not well understood, nor has persistence been the focus of economic theory. Fourth, despite the documented persistence, over longer horizons there are significant within-firm changes in board structure. In the next section, we explore the economic underpinnings of these changes.

\section{Dynamics of CEO tenure, board structure and pay}

\subsection{Conceptual links between performance, CEO tenure, and board structure}

Hermalin and Weisbach (1998) argue that board structure is an endogenous outcome of a bargaining process between the board and the CEO, conditional on estimated CEO ability (based on prior firm performance). While CEOs are assumed to prefer less monitoring, when the CEO's 
perceived ability is low or there is uncertainty about her ability, monitoring is valuable to the board. However, performance observations partially resolve this uncertainty and strong performance increases the board's perception of the CEO's ability, reducing the value of further monitoring. Therefore, when a firm performs well, the CEO is retained and is better able to bargain for reduced monitoring in addition to higher compensation. HW model reduced monitoring via fewer independent directors, and we add to that the CEO becoming board chair.

Dynamic agency theory produces similar predictions. ${ }^{19}$ In this class of models, the principal (board in our context) controls agency problems by tying the agent's (CEO in our context) current and future payoffs to performance and by maintaining a threat of monitoring or termination. In particular, following good performance, the CEO receives a higher continuation value (higher expected future payoff) in the firm. Since this higher future share of firm value helps align incentives, the termination threat is optimally eased, for example via less intense monitoring by the board. After a history of success, further incentive alignment becomes less important and thus, the strength of board monitoring decreases and cash compensation increases.

Likewise, continuation value falls after poor performance and if it hits a lower bound, the CEO is terminated. DeMarzo and Fishman (2007b) note that termination can also be interpreted as the introduction of a monitoring technology. Piskorski and Westerfield (2016) generate a similar prediction by directly incorporating a monitoring mechanism into the optimal contract: if bad behavior is detected, the CEO is fired and loses her continuation value. Because this penalty is more severe the larger the CEO's stake in the firm, the intensity of monitoring required to maintain incentives (and hence board independence) declines following a history of strong performance.

\footnotetext{
${ }^{19}$ E.g., Zwiebel (1996), DeMarzo and Sannikov (2006, 2017), DeMarzo and Fishman (2007a, 2007b), Bolton et al. (2011), DeMarzo et al. (2012) and Piskorski and Westerfield (2016).
} 
Thus, both bargaining and dynamic agency theories predict that (1) the board's monitoring intensity strengthens at the time of CEO turnover, then declines over a CEO's tenure within a given firm. ${ }^{20}$ We examine two measures of monitoring intensity: the fraction of independent directors and whether the CEO is appointed board chair. These models also predict that (2) the reduction in board independence over the CEO's tenure is more pronounced among CEOs who perform well. HW also predict that when the CEO has a stronger history of performance (and thus is more 'powerful') (3) CEO turnover is less sensitive to performance and (4) CEO compensation increases; and that (5) regulation that does not directly alter the contracting or bargaining environment may little affect overall board-CEO dynamics.

Note that many of these are dynamic, within-firm (or within-CEO) predictions, although in the past they have almost exclusively been tested in repeated cross-sections [a point emphasized in the Adams, Hermalin, and Weisbach (2010) review]. Thanks to our long panel of data, we are able to conduct powerful within-firm (and within-CEO) tests.

\subsection{Empirical analysis of CEO tenure, board structure and pay}

In Fig. 3, we explore the first prediction in a univariate fashion by showing average board independence as a function of CEO tenure at a given firm: Panel A shows that board independence decreases almost monotonically in CEO tenure, by 0.3 percentage points per year. In particular, the independence ratio is about $58 \%$ for new CEOs and $51 \%$ for those with 25 or more years of tenure. Panel B shows that CEOs with longer tenure are more likely to be board chairs as well. In particular, a one-year increase in tenure is associated with a 1.8 percentage-point increase in the probability that the CEO is a board chair.

\footnotetext{
${ }^{20}$ See HW, Proposition 4.
} 
While the univariate results are directionally consistent with Prediction (1) discussed above, they are based both on cross-sectional and within-firm variation. Thus, it is not clear whether the univariate results truly reflect within-firm (or within-CEO) changes in board structure or whether the types of CEOs that tend to have longer tenures are matched with firms that tend to have less independent boards. We test for a dynamic within-firm relation by estimating the following equation:

Board outcome $_{i t}=\alpha_{i}+\alpha_{t}+\beta_{1}$ CEO tenure $_{i t}+X_{i t}{ }^{\prime} \gamma+\varepsilon_{i t}$,

where Board outcomeit is either board independence, defined as the ratio of the number of independent directors to total directors, CEO-chair duality, or compensation (defined below); $\alpha_{i}$ and $\alpha_{t}$ represent firm and year fixed effects; the other variables are defined in Eq. (1). ${ }^{21}$

To benchmark to the prior literature, in column 1 of Table 4, Panel A we estimate Eq. (2) excluding firm fixed effects and focusing on the most recent 16 years of our sample period (19962011). ${ }^{22}$ The negative coefficient on CEO tenure $(-0.306$; $t$-stat $=-7.04)$ is consistent with prior findings (see Baker and Gompers, 2003; Boone et al., 2007; Dikolli et al., 2014 for evidence in repeated cross-sections of firms, without firm fixed effects) and has been interpreted as providing support for models such as HW. However, when we add firm fixed effects in column 2, the relation between CEO tenure and board independence is insignificant within firms. ${ }^{23}$ This contrast demonstrates the importance of controlling for firm effects to isolate the within-firm relation and suggests little dynamic relation between tenure and board independence in modern data.

In columns 3-6 of Table 4, Panel A, we extend the estimation to our full sample horizon of 1920-2011. Column 3 shows the basic relation between CEO tenure and board independence

\footnotetext{
${ }^{21}$ Our empirical results are robust to including two-digit SIC industry $\times$ year fixed effects (unreported).

${ }^{22}$ We use the 1996-2011 sample period to mimic a typical sample period for the IRRC board data, one of the most commonly used board datasets.

${ }^{23}$ When we include firm fixed effects, firm age drops out because it is collinear with year fixed effects within firms.
} 
within firms, including firm and year fixed effects but without firm-level controls. We find that board independence decreases by 0.15 percentage points per additional year of CEO tenure. The effect is statistically significant at the $1 \%$ level, and is the first evidence of a within-firm, dynamic relation between CEO tenure and board independence as opposed to across-firm relations. The economic magnitude indicates that ten years of CEO tenure would lead to a 1.5 percentage-point $(=0.15 \times 10)$ decrease in the independence ratio. While this represents $11.5 \%$ of a within-firm standard deviation of board independence (12.7 percentage points), given that the average board in our sample has about 10 directors, it suggests an average change of only 0.15 directors from independent to dependent over a decade. Thus, the effects of CEO tenure on board independence are modest in magnitude, consistent with the substantial persistence in board structure that we document in Section 3. We also note that if we do not control for year fixed effects, the withinfirm coefficient on CEO tenure becomes substantially smaller and statistically insignificant (unreported). This suggests the magnitude of the tenure effect is comparable to the long-term time trend in board structure (which year fixed effects control for) shown in Fig. 1, Panel C.

Column 4 controls for board size as well as additional firm characteristics including log assets, Tobin’s q, industry-adjusted ROA, and asset tangibility. These controls have little effect on the coefficient on CEO tenure and its significance level. The positive coefficient on board size is consistent with the cross-sectional findings in Boone et al. (2007) that board independence is positively associated with board size. Importantly, the negative coefficient on industry-adjusted ROA suggests that CEOs who perform well (relative to industry peers) face a less independent board.

Though firm fixed effects control for time-invariant firm-level omitted variables, the negative coefficient on CEO tenure could reflect a correlation between average tenure and board 
independence across CEOs within a firm, rather than a decline in board independence through the tenure of a given CEO. It is not feasible to estimate Eq. (2) with firm-CEO fixed effects, however, because tenure and year effects are perfectly collinear within each firm-CEO pair. As an alternative, in column 5, we use variation in tenure within a firm-CEO pair as an instrument, following Altonji and Shakotko (1987). Specifically, define $\overline{T_{l c}}$ and $\max T_{i c}$ as the average and maximum tenure for a given firm-CEO pair (indexed by $i$ and $c$, respectively). We then use $\left(T_{i c t}-\overline{T_{l c}}\right) / \max T_{i c}$ as an instrument for tenure. Intuitively, this transformation removes any differences in average tenure across firm-CEO pairs and measures the proportion of a given CEO's ultimate tenure that has been realized at each point in time. In this sense, this is a within-CEO measure.

Not surprisingly, the first stage (unreported) finds a very strong relation between the instrument and CEO tenure. The second stage results (shown in column 5) are similar to those in column 4 . The coefficient on instrumented CEO tenure is significantly negative and slightly larger in magnitude and statistical significance than the previous estimates. This suggests our previous results reflect within-CEO dynamics and are not simply driven by a cross-CEO relation between average tenure and board independence.

Column 6 estimates Eq. (2) without firm-fixed effects over the full sample period, which gives an idea of potential bias in such estimates. Compared to the coefficients in the other columns, the coefficient in column $6(-0.247)$ suggests that not isolating within-firm variation may lead to an estimate that is inflated by two-thirds. This significant difference in economic magnitude illustrates another important reason to measure this relation within firms.

Our data allow us to identify the within-firm relation between board independence and CEO tenure separately from that of a time trend because the data span the careers of multiple CEOs 
per firm. However, the importance of CEO turnovers for our identifying variation raises the question of whether our estimated tenure-independence relation may reflect a CEO turnover effect on board independence that is unrelated to the change in CEO tenure. To control for any turnoverspecific effects, in Appendix Table 2 we include the cumulative number of CEO turnovers per firm as an additional independent variable. The magnitude of the estimated coefficient on CEO tenure is smaller, but still highly statistically significant in this specification.

\subsection{Dynamics of board independence and variation in the CEO tenure effect}

Section 3 shows that board structure is persistent, while the previous subsection provides within-firm evidence that board independence declines through a CEO's career, though only modestly on average. In this subsection, we explore how this relation varies through the CEO's tenure and whether it is stronger conditional on past performance or other measures of CEO bargaining power. We begin by examining board structure year-by-year as a CEO's tenure increases.

In HW's bargaining model, the board is more likely to agree to a weaker monitoring structure when the marginal benefit of monitoring the CEO is lower. Monitoring becomes less valuable as the board's assessment of the CEO's ability increases or uncertainty about that ability decreases. HW Proposition 6 thus predicts that board independence is more likely to decline following strong performance. Likewise, in dynamic agency models, monitoring is less valuable when the agent has performed well and as a result accumulated large promised pay, which mitigates agency problems. More generally, the CEO's ability to decrease the monitoring intensity of the board should be a function of her bargaining power, which is likely to be lowest at the time of turnover and increase through her tenure, especially following strong performance. 
We therefore examine how board independence changes upon CEO turnover and how it evolves thereafter. Because the level of the CEO's perceived ability and promised pay should depend on the history of performance, we also study how the dynamics of board independence vary with firm performance. We explore these issues by estimating the following equation: Independence $_{i t}=\alpha_{i}+\alpha_{t}+\sum_{k=0}^{12} \gamma_{k} d_{i t}[k]+X_{i t}{ }^{\prime} \delta+\varepsilon_{i t}$.

The key independent variables in Eq. (3) are a set of indicator variables, $d[0], \ldots, d[12]$, corresponding to the firm-year observations from the year of CEO turnover to 12 years after the turnover. "Year -1" observations are also included in this analysis, serving as the baseline level. As before, this specification includes firm fixed effects, and thus examines within-firm dynamics following CEO turnover. We exclude CEO changes after 2002 from this analysis because it requires a post-turnover period. We also require that the previous CEO had at least two years of tenure and that the new CEO stays for at least two years.

4.3.1. Board dynamics for internal CEO hires. In this subsection, we explore how the dynamics of board independence vary with proxies for perceived CEO ability, using a sample of 3,761 turnovers from 1920 to 2002 for which the new CEO is a corporate insider. ${ }^{24}$ We initially focus on new insider CEOs because appointment of outsiders could affect board structure for reasons different than those related to the board's monitoring, which is our primary focus. In Section 4.6, we separately examine the effect of CEO turnover on board independence when the new CEO is an outsider.

Fig. 4 presents estimated $\gamma_{k}$ coefficients from Eq. (3), which can be interpreted as the percentage of board members who are independent by year of CEO tenure, relative to the firm's t1 level and after controlling for year fixed effects and firm characteristics. The y-intercept in Panel

\footnotetext{
${ }^{24}$ There are about twice as many insider- than outsider-appointed CEOs in our sample over the 1920-2011 period.
} 
A indicates that among firms appointing an insider CEO following the departure of the previous chief executive, board independence jumps in the year of turnover by about 0.60 percentage points (red dashed line). The increase is statistically significant at the $1 \%$ level and is about four times the average annual change estimated in Table 4 (Panel A) ${ }^{25}$ This finding is directionally consistent with bargaining models, since uncertainty about CEO ability is likely to jump at the time of turnover and the new CEO's bargaining power is likely to be lower than the incumbent's. In the context of dynamic agency models, it is also consistent with smaller continuation value for the new CEO and with the optimal contract being re-set for a new CEO. The graphs in Panel A thus indicate that the negative relation between board independence and CEO tenure comes from two sources: a jump at the time of CEO turnover, plus a gradual reduction in independence as tenure increases.

For the full sample, the plot indicates little change in board independence for the first eight years of a CEO's tenure. This is surprising from the standpoint of learning models like HW, as we would expect the most learning about CEO ability to occur in the first few years of tenure (see e.g., Pan, Wang, and Weisbach (2015) for related evidence). On the other hand, the level of uncertainty is also likely to be highest early in the CEO's tenure. In HW's model, this raises the value of monitoring to the board, making them less willing to reduce board independence. ${ }^{26}$

The blue solid line in Panel A represents the subset of new internal CEOs who are ultimately employed by their firms for at least 13 years. Hence, this analysis avoids possible changes in sample composition and focuses on CEOs who are successful enough to achieve long tenure. For these CEOs, board independence increases in the year of turnover (insignificant) and

\footnotetext{
${ }^{25}$ Dikolli, Mayew, and Nanda (2014) document an increase in board independence following CEO turnover among ExecuComp firms during 1996-2005. Denis and Sarin (1999) document that changes in board structure are stronger around executive turnover.

${ }^{26}$ See Proposition 1 and Corollary 1 in HW.
} 
begins to decrease soon afterward. The decreases from year $t$ to years $t+10$ and $t+12$ are $-2.18(t-$ stat $=-2.40)$ and $-3.03(t$-stat $=-2.89)$ percentage points. The decline in board independence is more pronounced than for the full sample, which may be because these CEOs survive longer as a reflection of superior job performance in their careers (hence less monitoring is needed). We examine this superior performance conjecture in Panel B. This also suggests that the lack of decline over the first eight years for the full sample is driven largely by CEOs who were less successful early in their tenures.

In Panel B, we compare less successful CEOs (those with below-median industry-adjusted ROA averaged over the first three years in office) in the red dashed line to more successful CEOs (above median) in the blue solid line. We find that board independence decreases faster for CEOs with better operating performance (ROA) in the early years of tenure. Similarly, Panel C shows that CEOs whose initial performance measured by industry-adjusted stock returns are above the median (blue solid line) exhibit decreasing board independence over their tenure, while those with below-median initial stock returns exhibit largely flat (even increasing somewhat initially) board independence ratios. The data in Panels B and C show that tenure-related reductions in board independence are evident among firms with superior performance but not among other firms.

In Table 4, Panel B, we more directly test the impact of performance on changes in board independence by estimating the following equation:

$\Delta$ Independence $_{i t}=\alpha_{i \times c}+\alpha_{t}+\beta_{1}$ Performance $_{i t}+\Delta X_{i t}{ }^{\prime} \gamma+\varepsilon_{i t}$,

where $\triangle$ Independence $e_{i t}$ is the first-difference in board independence; $\alpha_{i \times c}$ represents firm-by-CEO fixed effects; Performance $i t$ is a trailing three-year average (including year $t$ ) of either industryadjusted ROA or stock returns; $\Delta X_{i t}$ represents a vector of first-differenced firm-level control variables as in Eq. (1) (excluding Tobin's q and ROA) for firm $i$ in year $t$. To study the effect of 
firm performance on changes in board structure within a given CEO's career in the firm, we exclude observations when there is a CEO turnover. Further, including firm-by-CEO fixed effects in Eq. (4) controls for any remaining heterogeneity across CEO-firm pairs, so the coefficient is estimated off within-CEO variation.

Columns 1 through 3 show that the firm’s industry-adjusted ROA over the recent three years is significantly negatively associated with changes in board independence. For example, the estimates in column 2 suggest that a one-SD increase in ROA (0.080) is associated with a 0.24 percentage point greater decrease in the board independence ratio $(=-3.045 \times 0.080)$. Similarly, in columns 4 through 6, the coefficients on the firm's industry-adjusted stock returns over the recent three years are negative (though not statistically significant in column 6). The estimates in column 5 suggest that a one-SD increase in stock returns $(0.024)$ is associated with a 0.13 percentage point greater decrease in the board independence ratio $(=-5.504 \times 0.024)$. These findings are consistent with a larger decline in monitoring intensity following good industry-adjusted performance over the CEO’s tenure within a given firm.

In the context of executive compensation, Bertrand and Mullainathan (2001) show that CEOs are rewarded for industry performance, which they interpret as “pay for luck.” However, in an unreported analysis, we do not find a significant reduction in board independence following strong industry performance. The contrast in board dynamics following industry-adjusted vs. industry performance is consistent with CEOs gaining bargaining power through the perception of greater ability, rather than inefficient capture of the board (Bebchuk and Fried, 2004).

4.3.2. Succession tournaments. The CEO succession process (e.g., Vancil, 1987; Hermalin and Weisbach, 1988) is potentially an alternative explanation for the documented changes in board independence. In particular, toward the end of a CEO’s tenure the board may add directors who 
are candidates to become the next CEO. If these succession candidates are primarily insiders, this would push down board independence pre-turnover; and if the losing candidates leave the board right after the CEO change, this would increase board independence following CEO turnover.

We empirically examine whether such a CEO succession process accounts for the board dynamics we find by re-estimating Eq. (3) after excluding potential CEO candidates from our calculation of the board independence measure. We are not aware of any clear theoretical or empirical guidance on whether these CEO candidates should be concentrated in independent vs. dependent directors. Therefore, we first exclude any director who was added to the board within two years before a CEO turnover (i.e., years t-2 and t-1) and subsequently departs at turnover (Hermalin and Weisbach, 1988). ${ }^{27}$ Unreported results are very similar to those in Panel A of Fig. 4. Alternatively, we exclude only dependent directors who join just prior to CEO turnover and leave in the year of turnover. In this second case, we find little increase in board independence in the year of turnover, but a similar decline in independence through the CEO's tenure. Thus, depending on the specification, departure of losing CEO candidates may account for some of the jump in board independence at turnover; however, in our tests succession planning does not account for the decline in board independence after turnover.

4.3.3. Death- and health-related CEO turnover and board dynamics. Assigning a causal interpretation to the change in board structure at CEO turnover is difficult, because unobserved changes at the firm (e.g., variation in investment opportunities or strategy) may drive both CEO turnover and changes in board independence (e.g., Casamatta and Guembel, 2010). To address this challenge, we study a subsample of CEOs for whom turnover occurs for plausibly exogenous

\footnotetext{
${ }^{27}$ We find qualitatively similar results when we exclude directors who join the board within three years before CEO turnover then depart.
} 
reasons due to death of the previous $\mathrm{CEO}{ }^{28}$ This analysis also highlights how the CEO tenure effect on board independence varies with perceived CEO ability and related uncertainty. First, CEOs appointed in death transitions are likely to have less power than their predecessors, relative to new CEOs in the typical insider transition depicted in Panel A of Fig. 4. (Consistent with this conjecture, we find that the CEOs who died in office had longer tenure, and were much more likely to have been board chair, relative to typical CEOs who leave office.) Additionally, succession planning seems unlikely to explain results on this subsample as these firms will have had less opportunity for grooming the new CEO, increasing uncertainty about her ability in the job.

We estimate Eq. (3) using the 79 death-driven CEO turnover events that we are able to match to our CEO and board database in which the new CEO is an insider. The results (unreported) show that these CEO turnovers lead to an immediate increase in board independence of 1.9 percentage points in the year of turnover (significant at the $10 \%$ level), consistent with the results for the full sample. We also re-estimate Eq. (3) using these CEO death events as an instrument for CEO tenure. Thus, we exploit the death-driven departure of the prior CEO as the source of variation in CEO tenure in this analysis. The results (untabulated) from the first stage indicate that an exogenous CEO turnover is associated with an average reduction in CEO tenure of about nine years. The second stage shows an additional year of tenure is associated with a reduction in board independence of 0.22 percentage points (significant at the $10 \%$ level), which though still small, is slightly larger than the baseline Table 4 estimates.

\subsection{Dual chairs and CEO compensation}

Another dimension of board structure that may affect the monitoring of the CEO is whether the CEO is also board chair. Therefore, in the first two columns of Table 5 we examine whether

\footnotetext{
${ }^{28}$ See Appendix B for details about how we form this sample.
} 
CEO tenure is related to CEO-chair duality. Column 1 shows results from estimating Eq. (2) where the dependent variable is an indicator equal to one if the CEO also holds the title of board chair, and zero otherwise, ${ }^{29}$ using OLS with firm fixed effects. The positive coefficient estimate for $C E O$ tenure is the first within-firm evidence consistent with CEOs with longer tenure receiving the dual chair role. [Linck et al. (2008) and Dikolli et al. (2014) find a similar relation in the cross-section.] In terms of economic magnitude, an additional year of tenure in the same firm is associated with an increase of 2.2 percentage points (significant at the $1 \%$ level) in the probability that the CEO is board chair. Column 2, which uses the Altonji and Shakotko (1987) IV to capture within-CEO effects, shows similar magnitude and significance of the relation between tenure and CEO-chair duality.

Dynamic bargaining and agency models predict that CEO compensation will increase following a history of strong performance, proxied by increasing tenure. Columns 3 and 4 of Table 5 show results from estimating Eq. (2) with a dependent variable of the log of the CEO's total current compensation (salary and bonus). The sample consists of 3,323 firm-years from the combined database of corporate officers and directors merged with CEO compensation data drawn from Frydman and Saks (2010) from 1936 to 1991 and ExecuComp from 1992 to $2011 .{ }^{30}$ The significantly positive coefficients on CEO tenure in both columns indicate that CEOs are rewarded with higher compensation as their tenures increase. In terms of economic magnitude, each additional year of CEO tenure is associated with 2.4\% to 2.5\% higher pay (significant at the $1 \%$ level), beyond that associated with firm and year fixed effects and other included controls. In an

\footnotetext{
${ }^{29}$ To match the order of magnitude between estimates for board independence and CEO-chair duality, we multiply the indicator variable by 100 in the regression.

${ }^{30}$ We thank Carola Frydman for making the dataset of executive compensation from 1936 to 1991 available. For consistency across the sample, columns 3 and 4 of Table 5 only analyze 1992-2011 data for firms that appear in the Frydman and Saks database at least once.
} 
unreported analysis, we confirm a significantly positive within-firm effect of CEO tenure on pay (a 1.2\% increase per additional year of tenure) using the full sample of firm-years matched to ExecuComp from 1992 to 2009 ( $\mathrm{N}=11,715)$. Thus, consistent with HW (1998) and dynamic agency models (e.g., DeMarzo and Fishman, 2007a), compensation is path-dependent, increasing after a history of strong performance, proxied by an increase in CEO tenure.

4.5. CEO tenure and governance outcomes following 2002-2003 regulations, and substitution between board independence and chair duality

During 2002-2003, new regulations (e.g., imposed by SOX, NYSE, and NASDAQ) began to require that the majority of directors be independent (Chhaochharia and Grinstein, 2007; Linck et al., 2008; Duchin et al., 2010). These regulations therefore might attenuate the relation between CEO tenure and board independence. To evaluate this conjecture, Table 6 examines the association between CEO tenure and board independence, chair duality, and CEO compensation for years before and after 2002 by re-estimating Eq. (2), adding an interaction between CEO tenure and an indicator for years after 2002. In this specification, we also interact the firm fixed effects with the post-2002 indicator in order to control for any within-firm shifts in the average level of board independence, chair duality, and compensation following the regulation changes. In column 1 , where the dependent variable is board independence, the coefficient on CEO tenure $\times$ Post 2002 is 0.140 , suggesting that after 2002, CEO tenure has no significant impact on board independence $(-0.155+0.140=-0.015 ; t$-stat $=-0.37)$. This may explain the lack of a relation between CEO tenure and board structure in Coles et al. (2014), given their 1996 - 2010 sample period (and in our finding of insignificance over a similar horizon in column 2 of Table 4, Panel A).

While the regulations increased board independence as intended, Hermalin and Weisbach (1998, p. 111) argue that "As long as the bargaining process [between the CEO and board] itself 
is unaffected by reforms, the equilibrium will be little affected.” Thus, we might expect that successful CEOs receive greater rewards in other dimensions. Consistent with this implication, the coefficient on CEO tenure $\times$ Post 2002 is $1.309(t$-stat $=5.33)$ in column 2, where the dependent variable is an indicator for CEO-chair duality $(\times 100) .{ }^{31}$ This increased chair duality for longtenured CEOs after 2002 is consistent with a substitution towards a dual chair role (and thus less monitoring) due to higher board independence (and thus more monitoring) following the implementation of Sarbanes-Oxley and related regulations. More generally, in Appendix Table 1, Panels A and B, we find evidence consistent with a substitution between board independence and chair duality over the past century. Specifically, across the century, in sub-periods when the withinfirm relation between CEO tenure and board independence is weaker, the within-firm relation between tenure and the CEO being appointed board chair is stronger. Finally, column 3 in Table 6 explores whether the regulations affected compensation. The coefficient on CEO tenure $\times$ Post 2002 is -0.008 and insignificant, suggesting no change in the tenure-compensation relation post2002.

In Panel D of Fig. 4, we examine another potential aspect of the substitution between board independence and dual chair titles: relative timing within CEO tenure. ${ }^{32}$ The panel shows that CEOs are appointed as dual chairs in the early years of tenure, with the dual chair effect leveling off just as board independence begins to decline more steeply as shown in Panel A.

\subsection{External CEO appointments}

We now examine board dynamics when an external CEO is appointed (i.e., not a previous officer of the firm). Given that a new outsider CEO likely has less experience or expertise with the

\footnotetext{
${ }^{31}$ Linck et al. (2008) find that the cross-sectional relation between CEO tenure and chair duality also increases post SOX.

${ }^{32}$ We thank the referee for suggesting this test.
} 
firm than does an insider, hiring an outsider may increase the benefit of having inside directors on the board, due to their ability to provide firm-specific knowledge and advice. ${ }^{33}$ In Panel E of Fig. 4, the patterns for external CEOs differ from those in the earlier panels. Board independence decreases by 3.1 percentage points in the turnover year when the new CEO is an external hire, in stark contrast to results for new internal CEOs. The decrease is significant at the $1 \%$ level. Board independence increases rapidly in the first few years of an outsider CEO's tenure, offsetting most of the initial decline by year $t+6$. The increase from years $t$ to $t+6$ is significant at the $1 \%$ level. This pattern is consistent with the new external CEO gaining more experience within the firm, reducing the need for internal advisor-directors on the board. Board independence eventually shows the familiar decrease only after year $t+9$.

These differing results for outside CEOs are new to the literature. For this subset of firms, other factors, such as the value of firm-specific knowledge on the board, appear to outweigh any effects related to learning and contracting between the board and CEO. More theoretical and empirical research is needed to investigate these issues.

\section{Effect of CEO power on CEO turnover-performance sensitivity}

The analysis in Section 4 provides some evidence consistent with CEOs being monitored less intensely and gaining power over their tenures, especially conditional on strong performance. Does this imply that the jobs of successful CEOs are relatively protected, and if so, do long-tenure CEOs eventually become entrenched and adversely affect firm value? To investigate these

\footnotetext{
${ }^{33}$ Mace (1971) argues that expertise of outside directors facilitates the advisory role of the board. Adams and Ferreira (2007) argue that a management friendly (less independent) board can facilitate the information sharing that supports the advisory role. Our finding is consistent with Adams and Ferreira's argument but the difference is that we focus on external CEOs while they do not differentiate between internal and external CEOs.
} 
questions, we start by examining CEO replacement conditional on performance. ${ }^{34}$ Bargaining models like HW, in which the board learns CEO ability from realized performance, predict that previously successful CEOs would be optimally fired less often conditional on poor current performance. Likewise, in dynamic contracting models, a history of good performance results in continuation values well above the termination threshold, making termination less sensitive to current performance.

We begin by estimating a linear probability model with firm fixed effects to predict CEO turnover from 1926 to 2011, conditional on firm performance and CEO power (for analysis on modern data, see Weisbach, 1988; Warner, Watts, and Wruck, 1988; Jenter and Lewellen, 2014). We start the estimation in 1926 to align with the availability of CRSP data. Specifically, we estimate the following equation using OLS: 35

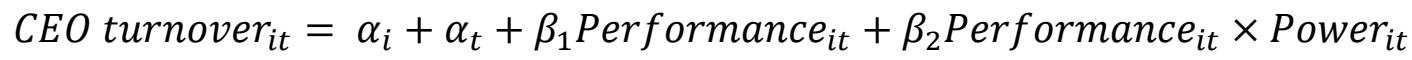
$+\beta_{3}$ Performance $_{i t-1}+\beta_{4}$ Performance $_{i t-1} \times$ Power $_{i t}+\beta_{5}$ Power $_{i t}+X_{i t}{ }^{\prime} \delta+\varepsilon_{i t}$,

where CEO turnover it is an indicator variable equal to one if the current CEO is different from the previous year's CEO, and zero otherwise; Performance $i t$ is either of $\triangle R O A_{i t}$, the change in return on assets or Excess return $i$, the stock return minus value-weighted market return from CRSP; Power $_{i t}$ is one of four proxies that measure bargaining power or superior past performance: Board independence, CEO-chair duality, ROA or stock returns over the first three years of the CEO's tenure, and CEO tenure (Adams, Almeida, and Ferreira, 2006; Morse, Nanda, and Seru, 2011); ${ }^{36}$ $X_{i t}$ is a vector of firm-level controls including CEO tenure, log book assets, and Tobin's q for firm

\footnotetext{
${ }^{34}$ We proxy for the decision to fire the CEO using a CEO turnover indicator equal to one if the current CEO is different from the previous year's CEO, and equal to zero otherwise (see, e.g., Jenter and Lewellen, 2014).

${ }^{35}$ We find qualitatively similar results using logit models with firm fixed effects (i.e., conditional logit).

${ }^{36}$ In the presented analysis, we use an indicator variable for the top (ROA, stock return, and tenure) or bottom quartile (independence) of the full sample to define powerful CEOs (except for the dual chair indicator). Our results are robust to alternative specifications that use other percentiles of distributions (e.g., the median) or continuous variables to measure CEO power.
} 
$i$ in year $t$; and standard errors are clustered at the firm level. ${ }^{37}$ Eq. (5) enhances the specification in Weisbach (1988) and Warner et al. (1988) by including firm fixed effects to account for firmlevel heterogeneity in the propensity to replace the CEO and extending their analysis across the century. Given the high correlation between the two performance measures, we separately estimate Eq. (5) by employing the change in ROA (Panel A) or excess stock returns (Panel B).

We first benchmark that CEO turnover is significantly negatively associated with performance, as measured either by the change in ROA or excess stock returns, consistent with prior research (see Appendix Table 3).$^{38}$ Our focus is on the effects of CEO power on CEO turnover-performance sensitivity. We start with the classic proxy for monitoring intensity of the board: the board independence ratio. Column 1 of Table 7 shows that less independent boards are associated with significantly lower performance sensitivity of CEO turnover, consistent with Weisbach’s (1988) cross-sectional finding. Column 2 uses an indicator variable for CEO-chair dual title as a proxy for CEO power and shows that dual chair-CEOs face a significantly lower sensitivity of turnover to contemporaneous performance measured by either changes in ROA or excess stock returns (see Goyal and Park, 2002 for cross-sectional evidence). ${ }^{39}$

Column 3 (4) defines power based on firms in the top quartile of ROA (stock returns) in the first three years of the CEO's tenure. In these columns, we include only observations for CEOs with at least four years of tenure, to ensure that average performance during the CEO's first three years is well measured. We find that current performance has little effect on turnover propensity for CEOs who performed well over the first three years of their careers at their current firms. ${ }^{40}$

\footnotetext{
${ }^{37} \mathrm{CEO}$ age is not available in Moody's or Mergent; thus, we do not include it as a control variable.

${ }^{38}$ See, for example, Warner, Watts, and Wruck (1988), Weisbach (1988), Murphy and Zimmerman (1993) and Jenter and Lewellen (2014).

${ }^{39}$ This column uses data starting in 1960, to coincide with the timing of when there is less ambiguity in whether the CEO is dual board chair.

${ }^{40}$ In some cases in columns 3 and 4, the sum of the coefficients on Performance and Performance $\times$ Power are even slightly positive.
} 
Overall, these results are consistent with powerful and previously successful CEOs being somewhat shielded from board monitoring and, in particular, the risk of being fired due to poor firm performance. The one exception is in column 5, where we measure CEO power with a "long tenure” indicator equal to one if CEO tenure is larger than its third quartile (nine years). In this case, only one of the four coefficients on the interactions between performance and CEO power is significantly positive. Thus, while by most measures more powerful CEOs face lower performance-turnover sensitivity, this greater power may not be achieved through longer tenure alone. This is consistent with our results in Section 4.3 that show that the negative CEO-tenure relation holds primarily for high-performing CEOs. ${ }^{41}$

\section{Market reaction to sudden departures of CEOs}

The results in the previous sections provide some evidence that bargaining or dynamic contracting affects board structure and chief executive retention decisions. This begs an important question: Do CEOs who have gained power through a history of superior performance in a given firm continue to add value to the firm (consistent with them having "high ability" or a larger stake in the firm), or do they become entrenched and potentially reduce value ex post? To address this question, we examine market reactions to CEO turnover, conditional on the power or past success of the departing CEO. To examine plausibly exogenous CEO turnover, we use events of death and health-related CEO turnover from 1950 to 2011 (see, e.g., Bennedsen, Perez-Gonzalez, and Wolfenzon, 2010; Jäger, 2016). ${ }^{42}$ We first calculate market-adjusted excess daily stock returns as $\varepsilon_{i t}=R_{i t}-R_{m t}$, where $R_{i t}$ is the rate of stock return for firm $i$ on day $t$, and $R_{m t}$ is the rate of return

\footnotetext{
${ }^{41}$ Dikolli et al. (2014) show that performance-related CEO turnover declines in CEO tenure for Execucomp firms. As mentioned above, our analysis includes firm fixed effects and hence tests the within-firm theoretical prediction.

${ }^{42}$ Previous research finds generally weak average announcement returns around CEO turnover due to death of the CEO (see, e.g., Johnson et al., 1985; Jenter et al., 2019).
} 
for the market portfolio ("vwretd" from CRSP). We then compute cumulative excess returns during the $[-2,+2]$ window around the announcement of CEO turnover by compounding the daily excess returns. $^{43}$

See Appendix B for details on how we gather data on CEO death and health events. To increase sample size, in this section we include NASDAQ firms in addition to NYSE/AMEX firms. This sample selection process results in 336 events with matched information on directors and officers. The average cumulative abnormal return for death and health events is $0.84 \%$, which is similar to the $0.66 \%$ average buy-and-hold-abnormal return during the month of death announcement documented by Jenter, Matveyev, and Roth (2019).

Table 8 shows the results of regressing cumulative excess return in response to plausibly exogenous CEO turnover on various proxies for CEO power: (1) An indicator for CEO tenure above the third quartile, (2) an indicator for whether the CEO is board chair, and (3) an indicator for whether the CEO is the founder of the firm. Across the columns of Panel A, death and healthrelated CEO turnover is associated with $2.7 \%$ to $3.1 \%$ higher announcement returns when the departing CEO was more powerful, and the differences are significant at the $1 \%$ to $5 \%$ levels. In contrast, departures of CEOs who had relatively little power before leaving office entail insignificant announcement returns ranging from $-1.3 \%$ to $0.6 \%$, as captured by the intercepts. ${ }^{44}$ To mitigate concerns that some health-related departures may be partially anticipated by the market, in Panels B and C, we restrict the sample to only death-related and sudden death-related departures, respectively. Panel B shows that announcement returns for death-driven CEO turnover

\footnotetext{
${ }^{43}$ The results are robust to alternative event windows such as [-3, +3], [-2, +3], and [-1, +2].

${ }^{44}$ Salas (2010) finds that market reactions to deaths of older, longer tenured, and founder CEOs are significantly positive only when their firms performed poorly in the years prior to the death. Johnson et al. (1985) find positive reactions to the deaths of founder CEOs. In a contemporaneous paper, Jenter et al. (2019) find an insignificant positive reaction to sudden founder deaths when controlling for CEO age and tenure. Our analysis in this section complements these findings by using comprehensive data on CEO death-driven turnovers from 1950 to 2011 and documenting how the market reacts to the death of a CEO conditional on several measures of CEO power.
} 
are $3.1 \%$ to $3.9 \%$ higher when the CEO is more successful. Panel C provides similar evidence for sudden deaths ( $N$ 149), although for one of the three measures of CEO power (chair duality) the market reaction to sudden deaths is insignificant (though still positive at 2.0\%; $t$-stat $=1.33$ ). These findings are consistent with the argument that powerful CEOs can become entrenched or extract excess pay, and thus removing these CEOs (which presumably would have been costly without a death occurrence) would increase shareholder value. Note that the economic magnitudes of our estimates in Table 8 are similar to those in Taylor (2010), who uses a structural model to estimate that shareholder value would increase by $3 \%$ if the perceived cost of removing (entrenched) CEOs was eliminated.

Does entrenchment fit with the bargaining and contracting models we rely on as a framework? On the one hand, in dynamic learning models such as HW, CEOs who achieve long tenures and gain power over the board are those perceived to be of high skill. Under this interpretation, we would not expect the market to react positively to unexpected departures of these highly skilled CEOs. In that sense, the positive reactions we document appear more consistent with the view that over time CEOs inefficiently gain excess power over the board (e.g., Bebchuk and Fried, 2004).

We note, however, that our evidence is not necessarily inconsistent with optimal learning and/or contracting models. For example, as HW discuss in a verbal extension to their formal model, if insiders prefer to retain the incumbent CEO and the board becomes less independent over time, such a framework could lead to entrenchment ex-post. The positive market reaction can also be interpreted as consistent with dynamic contracting in that ex-post entrenchment (as a nonpecuniary benefit) may provide the agent incentives ex ante. The market reaction is also consistent with promised future rents to the CEO reverting back to the firm upon the CEO's death. Thus, we 
might think of these positive market reactions as an ex-post measure of the cost of agency conflicts, even if firms are ex ante optimizing board structure conditional on these frictions.

\section{Conclusion}

We analyze about 87,000 firm-year observations over 92 years to explore dynamic interactions between the CEO and board of directors. Our long panel of data allows us to investigate potentially slow-moving governance and contracting processes. We find that board structure is persistent: board independence lagged 10 or 20 years is by far the strongest predictor of current period board independence, suggesting that a board once weakened (or strengthened) may remain so far into the future. Future research should attempt to uncover the frictions or other forces behind this persistence. Despite persistent board structure, our long sample enables us to examine whether the board changes that do occur are consistent with theories of board dynamics. We find some results that are consistent with theoretical predictions from bargaining and dynamic agency models but others that are less so.

In particular, consistent with successful CEOs gaining power or higher continuation value at their firms, we find that board independence decreases as a given CEO's tenure increases. The within-firm CEO tenure-board independence relation is stronger when board incentives to monitor weaken, such as following strong corporate performance. And board independence jumps at CEO

turnover, when uncertainty about the CEO's ability spikes and CEO power is low. We also find that CEOs are more likely to become board chair and earn higher compensation over their tenures. Further, powerful CEOs and those with a history of strong performance are less likely to be replaced conditional on poor current performance. 
However, we document several new findings that do not fit as neatly within standard interpretations of dynamic bargaining and contracting governance theory:

- The negative board independence-CEO tenure relation is small in economic magnitude and small relative to other forces in the data. Related, despite a statistically significant relation with CEO tenure, board structures are quite persistent.

- Board independence declines when an external CEO is appointed, opposite the monitoring prediction (though perhaps consistent with external CEOs benefiting more from the advice of insider directors than from monitoring).

- We find no market reaction to the typical CEO death, but a positive reaction when powerful (long-tenure, dual board chair, founder) CEOs die in office. Among other interpretations, this result is consistent with powerful CEOs becoming entrenched in the sense that an unexpected departure would increase firm value.

More theoretical and empirical research is needed to reconcile these results with extant (or new) governance theory.

We also document new results related to CEOs being appointed dual board chair. Consistent with appointing the CEO as dual board chair being a substitute to reduced board independence, we find that 1) being appointed dual chair is concentrated in the early years of a CEO's tenure while the reduction in board independence on average occurs later; and 2) successful CEOs were more likely to be appointed board chair following 2002 regulations that increased board independence. Further research is needed to model the monitoring implications of CEOchair duality and the substitution between dual chairs and board independence.

Overall, our evidence is consistent with the life-cycle of powerful CEOs being that they are successful early in their careers and hence gain power within their firms, which leads to job security, dual chair roles and greater pay, and eventually leads to powerful CEOs becoming entrenched (on average). Given that these results are likely to be equilibrium outcomes of a dynamic bargaining or contracting process, our tests do not always allow us to prove causality of these results, but they do suggest interesting avenues for future research. 


\section{References}

Adams, R., Almeida, H., and Ferreira, D., 2006. Powerful CEOs and their impact on corporate performance. Review of Financial Studies 18, 1430-1432.

Adams, R., Ferreira D., 2007. A theory of friendly boards. Journal of Finance 62, 217-250.

Adams, R., Hermalin, B., Weisbach, M., 2010. The role of boards of directors in corporate governance: a conceptual framework and survey. Journal of Economic Literature 48, 58-107.

Altonji, J., Shakotko, R., 1987. Do wages rise with job seniority? Review of Economic Studies 54, 437-459.

Avedian, A., Cronqvist, H., Weidenmier, M., 2015. Corporate governance and the creation of the SEC. Unpublished working paper. Harvard University, University of Miami, and Claremont Colleges.

Baker, M. and Gompers, P., 2003. The determinants of board structure at the initial public offering. Journal of Law and Economics 42, 569-598.

Bebchuk, L. A., Fried, J. M., Walker, D. I., 2002. Managerial power and rent extraction in the design of executive compensation, University of Chicago Law Review 63, 751-846.

Bebchuk, L. A., Fried, J. M., 2003. Executive compensation as an agency problem, Journal of Economic Perspectives 17, 71-92.

Bebchuk, L. A., Fried, J. M., 2004. Pay without Performance: The Unfulfilled Promise of Executive Compensation, Harvard University Press, Boston.

Bennedsen, M., Perez-Gonzalez, F., Wolfenzon, D., 2010. Do CEOs matter? Unpublished working paper. INSEAD, Stanford University, and Columbia University.

Bertrand, M., Mullainathan, S., 2001. Are CEOs rewarded for luck? The ones without principals are, Quarterly Journal of Economics 116, 901-932.

Bolton, P., Chen, H., Wang, N., 2011. A unified theory of Tobin's q, corporate investment, financing, and risk management. Journal of Finance 66, 1545-1578.

Boone, A., Field, L., Karpoff, J., Raheja, C., 2007. The determinants of corporate board size and composition: an empirical analysis. Journal of Financial Economics 85, 66-101.

Casamatta, C., Guembel, A., 2010. Managerial legacies, entrenchment, and strategic inertia. Journal of Finance 65, 2403-2436.

Chhaochharia, V., Grinstein, Y., 2007. Corporate governance and firm value: The impact of the 2002 governance rules. Journal of Finance 62, 1789-1825.

Cicero, D., Wintoki, M., Yang, T., 2013. How do public companies adjust their board structures? Journal of Corporate Finance 23, 108-127.

Coles, J., Daniel, N., Naveen, L., 2008. Boards: Does one size fit all?. Journal of Financial Economics 87, 329356.

Coles, J., Daniel, N., Naveen, L., 2014. Co-opted boards. Review of Financial Studies 27, 1751-1796. 
Dahya, J., McConnell, J., Travlos, N., 2002. The Cadbury committee, corporate performance, and top management turnover. Journal of Finance 57, 461-483.

DeAngelo, H., Roll, R., 2015. How stable are corporate capital structures? Journal of Finance 70, 373-418.

DeMarzo, P., Sannikov, Y., 2006. Optimal security design and dynamic capital structure in a continuous-time agency model. Journal of Finance 61, 2681-2724.

DeMarzo, P., Fishman, M., 2007a. Agency and optimal investment dynamics. Review of Financial Studies 20, 151-188.

DeMarzo, P., Fishman, M., 2007b. Optimal long-term financial contracting. Review of Financial Studies 20, 2079-2128.

DeMarzo, P., Fishman, M., He, Z., Wang, N., 2012. Dynamic agency and the q theory of investment. Journal of Finance 67, 2295-2340.

DeMarzo, P., Sannikov, Y., 2017. Learning, termination, and payout policy in dynamic incentive contracts. Review of Economic Studies 84, 182-236.

Denis, D., Sarin, A., 1999. Ownership and board structures in publicly traded corporations. Journal of Financial Economics 52, 187-223.

Dikolli, S., Mayew, J., Nanda, D., 2014. CEO tenure and the performance-turnover relation. Review of Accounting Studies 19, 281-327.

Duchin, R., Matsusaka, J., Ozbas, O., 2010. When are outside directors effective? Journal of Financial Economics 96, 195-214.

Fee, C., Hadlock, C., Pierce, J., 2013. Managers with and without style: evidence using exogenous variation. Review of Financial Studies 26, 567-601.

Frydman, C., Saks, R., 2010. Executive compensation: A new view from a long-term perspective, 1936-2005. Review of Financial Studies 23, 2099-2138.

Frydman, C., Hilt, E., Zhou, L., 2015. Economic effects of early 'shadow banks': Trust companies and the panic of 1907. Journal of Political Economy 123, 902-940.

Goyal, V., Park, C., 2002. Board leadership structure and CEO turnover. Journal of Corporate Finance 8, 4966.

Graham, J., Leary, M., Roberts, M., 2015. A century of capital structure: The leveraging of corporate America. Journal of Financial Economics 118, 658-683.

Hermalin, B., Weisbach, M., 1988. The determinants of board composition. RAND Journal of Economics 19, 589-606.

Hermalin, B., Weisbach, M., 1998. Endogenously chosen boards of directors and their monitoring of the CEO. American Economic Review 88, 96-118.

Huson, M., Parrino, R., Starks, L., 2001. Internal monitoring mechanisms and CEO turnover: A long-term perspective. Journal of Finance 56, 2265-2296. 
Jäger, S., 2016. How substitutable are workers? Evidence from worker deaths. Unpublished working paper. Harvard University.

Jenter, D., Lewellen, K., 2014. Performance-induced CEO turnover. Unpublished working paper. Stanford University and Dartmouth College.

Jenter, D., Matveyev, E., Roth, L., 2019. Good and bad CEOs. Unpublished working paper. London School of Economics and University of Alberta.

Johnson, W., Magee, R., Nagarajan, N., Newman, H., 1985. An analysis of the stock price reaction to sudden executive deaths: Implications for the managerial labor market. Journal of Accounting and Economics 7, 151-174.

Kaplan, S., Minton, B., 2012. How has CEO turnover changed? International Review of Finance 12, 57-87.

Lehn, K., Patro, S., Zhao, M., 2009. Determinants of the size and composition of US corporate boards. Financial Management 38, 747-780.

Lemmon, M., Roberts, M., Zender, J., 2008. Back to the beginning: Persistence and the cross-section of corporate capital structure. Journal of Finance 63, 1575-1608.

Linck, J., Netter, J., Yang, T., 2008. The determinants of board structure. Journal of Financial Economics 87, 308-328.

Mace, M., 1971. Directors: Myth and Reality. Harvard Business School Press, Boston.

Marosi, A., Massoud, N., 2008. You can enter but you cannot leave...: U.S. securities markets and foreign firms. Journal of Finance 63, 2477-2506.

Morse, A., Nanda, V., Seru, A., 2011. Are incentive contracts rigged by powerful CEOs? Journal of Finance 66, 1779-1821.

Murphy, K., Zimmerman, J., 1993. Financial performance surrounding CEO turnover. Journal of Accounting and Economics 16, 273-315.

Murphy, K., Zabojnik, J., 2007. Managerial capital and the market for CEOs. Unpublished working paper, University of Southern California and Queen's University.

National Association of Corporate Directors, 1996. NACD Blue Ribbon Commission on Director Professionalism.

Pan, Y., Wang, T., Weisbach, M., 2015. Learning about CEO ability and stock return volatility. Review of Financial Studies 28, 1623-1666.

Piskorski, T., Westerfield, M., 2016. Optimal dynamic contracts with moral hazard and costly monitoring. Journal of Economic Theory 166, 242-281.

Quigley, T., Crossland, C., Campbell, R., 2017. Shareholder perceptions of the changing impact of CEOs: Market reactions to unexpected CEO deaths, 1950 - 2009. Strategic Management Review 38, 939-949.

Salas, J., 2010. Entrenchment, governance, and the stock price reaction to sudden executive deaths. Journal of Banking and Finance 34, 656-666. 
Taylor, L., 2010. Why are CEOs rarely fired? Evidence from structural estimation. Journal of Finance 65, 20512087.

Vancil, R., 1987. Passing the Baton. Harvard University Press, Boston.

Wangler, L., 1994. The Real World of Separate Chairmen.

Warner, J., Watts, R., Wruck, K.,1988. Stock prices and top management changes. Journal of Financial Economics 20, 461-492.

Weisbach, M., 1988. Outsider directors and CEO turnover. Journal of Financial Economics 20, 431-460.

Zwiebel, J., 1996. Dynamic capital structure under managerial entrenchment. American Economic Review 86, 1197-1215. 


\section{Figure 1: Long-run CEO and board trends}

This figure shows annual means of CEO turnover (Panel A), the proportion of non-affiliated CEO appointments (Panel B), board independence (Panel C), and the percentage of CEOs who are also board chairs (Panel D). Blue solid (red dashed) lines show averages (average regression residuals after controlling for firm characteristics, including firm age, log board size, log book assets, Tobin's q, two-digit SIC industry-adjusted return on assets, and asset tangibility). Panels A and B plot three-year moving averages. For Panels B and C, the sample begins in 1933 given that identification of outside CEOs and dependent directors relies on historical observations for given firms.

\section{Panel A: CEO turnover (three-year moving average)}

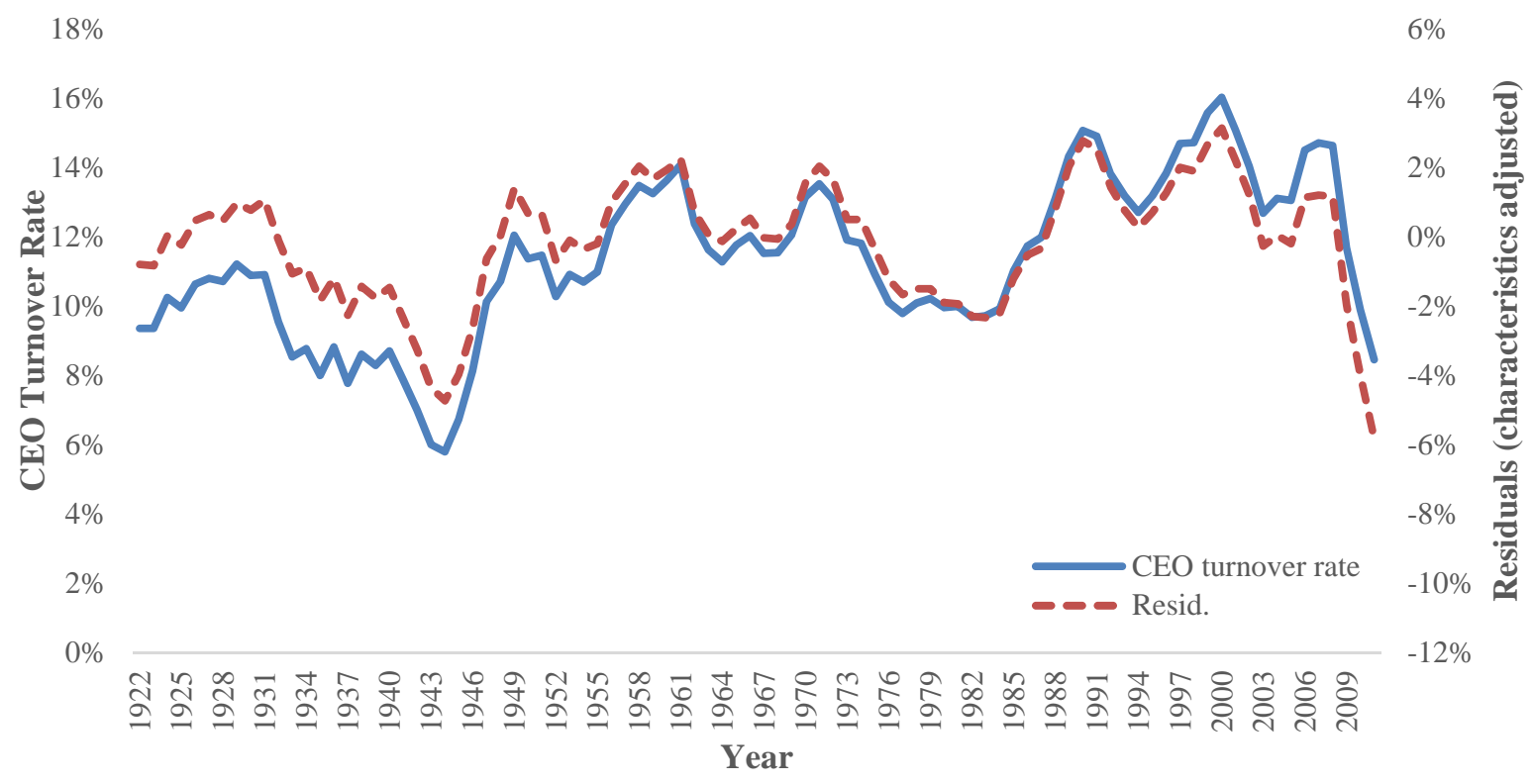

\section{Panel B: Outside CEO appointment (three-year moving average)}

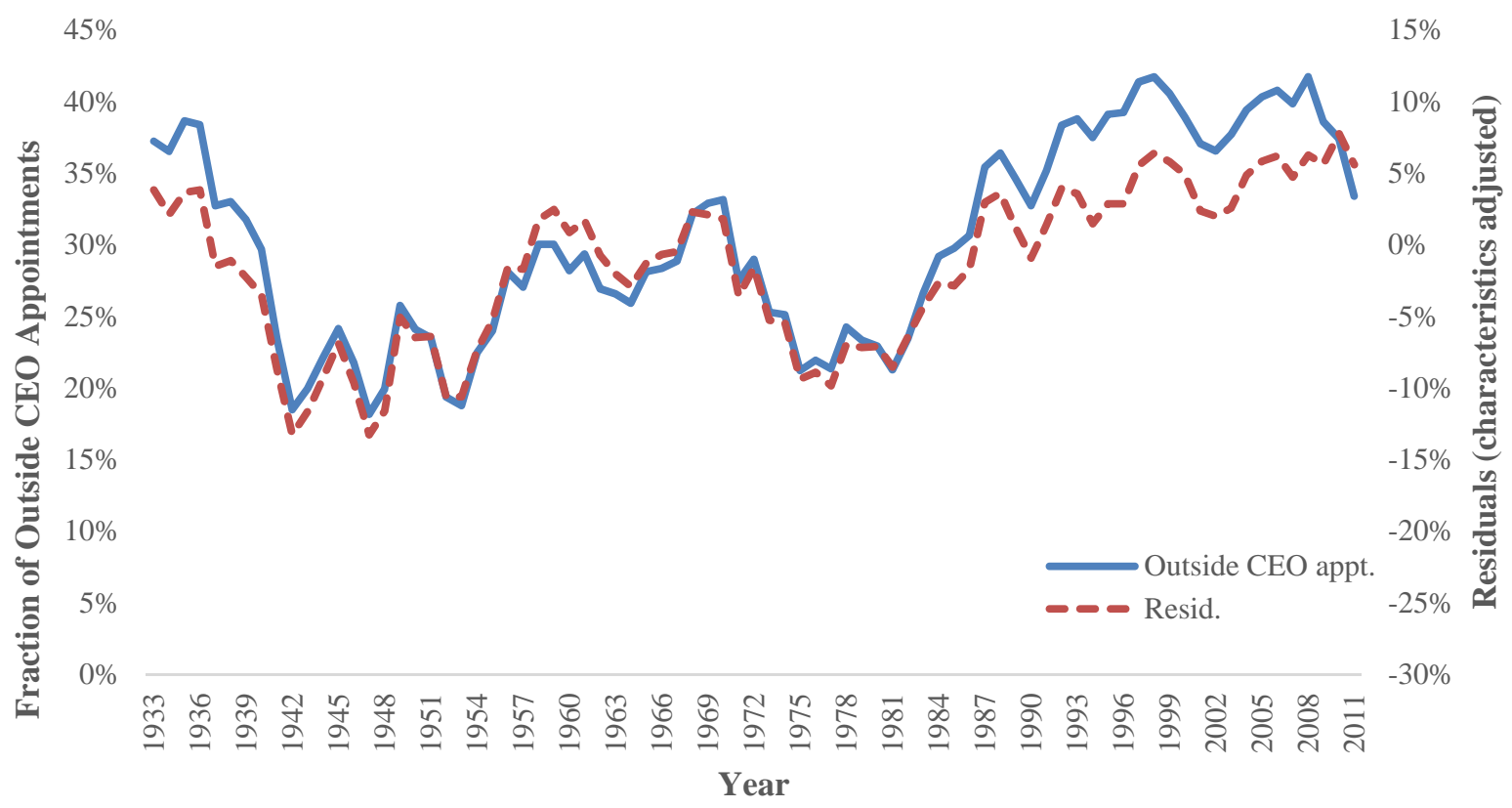




\section{Panel C: Board independence}

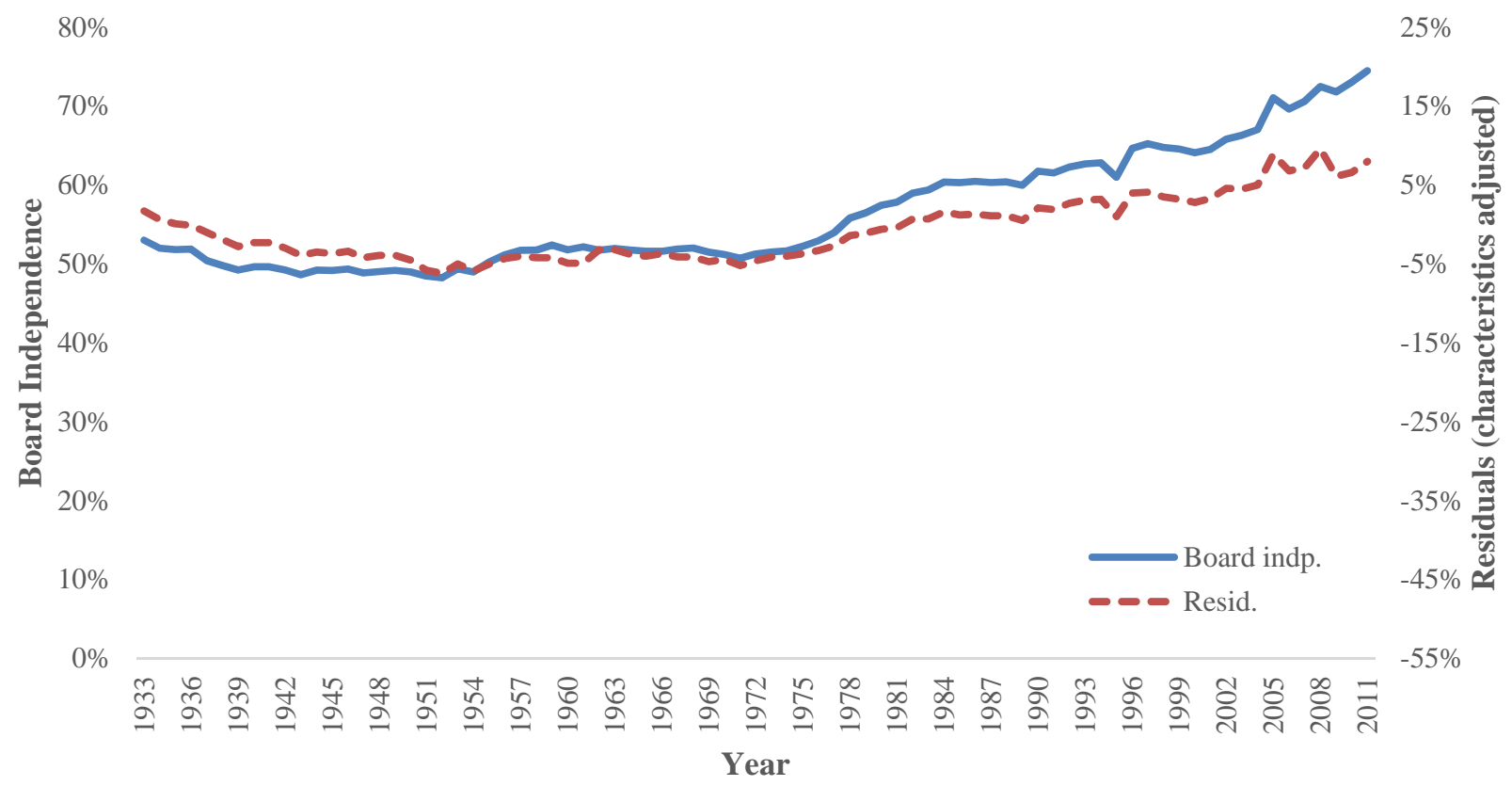

\section{Panel D: CEO-chair duality}

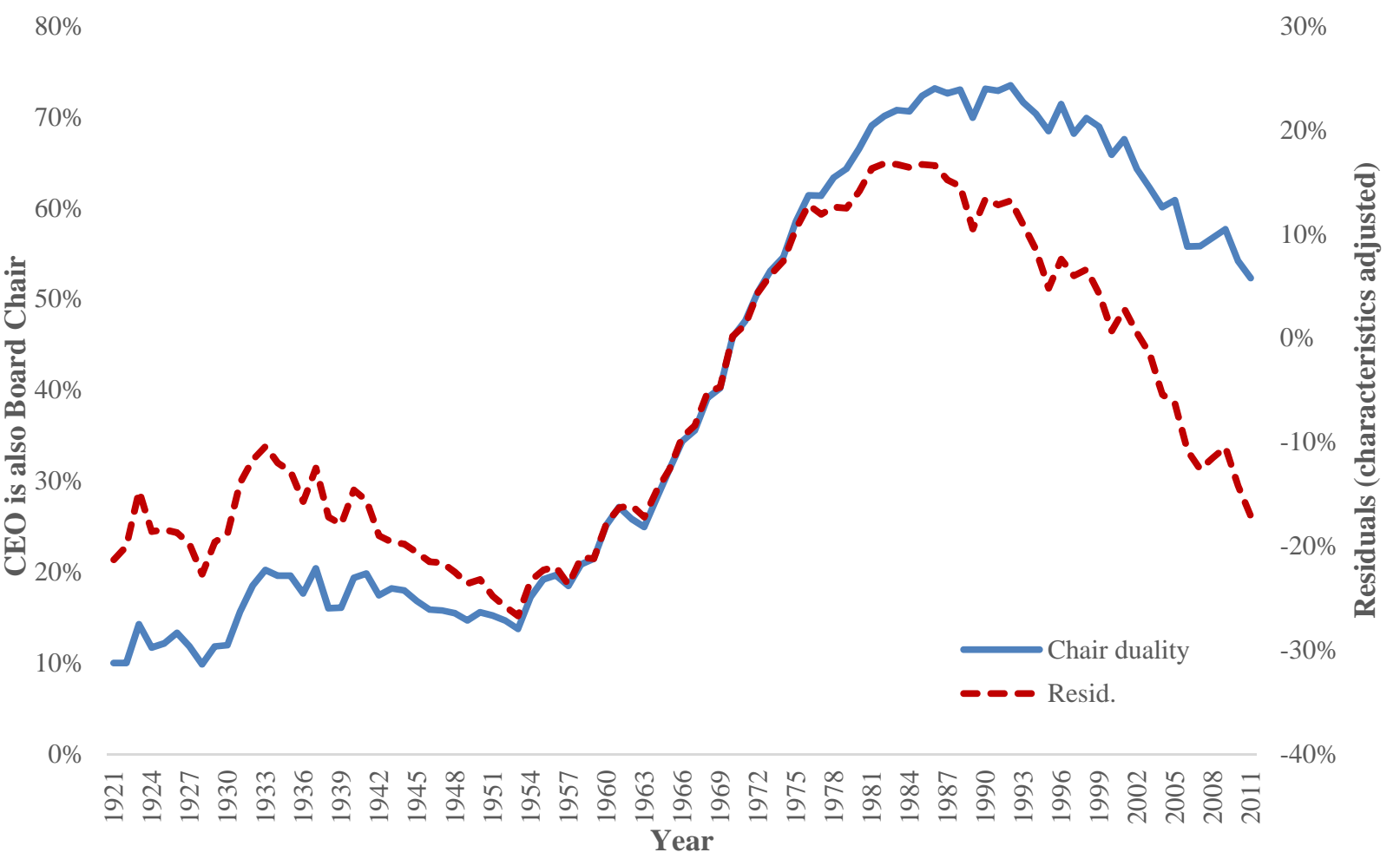




\section{Figure 2: Persistence of board independence}

This figure presents the dynamics of board independence for firms sorted into quartiles based on the initial level of the board independence ratio. Specifically, for each calendar year, we form groups by ranking firms based on their independence ratios and compute the groups' average board independences for the next 30 years. We repeat this process for all calendar years and report the average across all the calendar years.

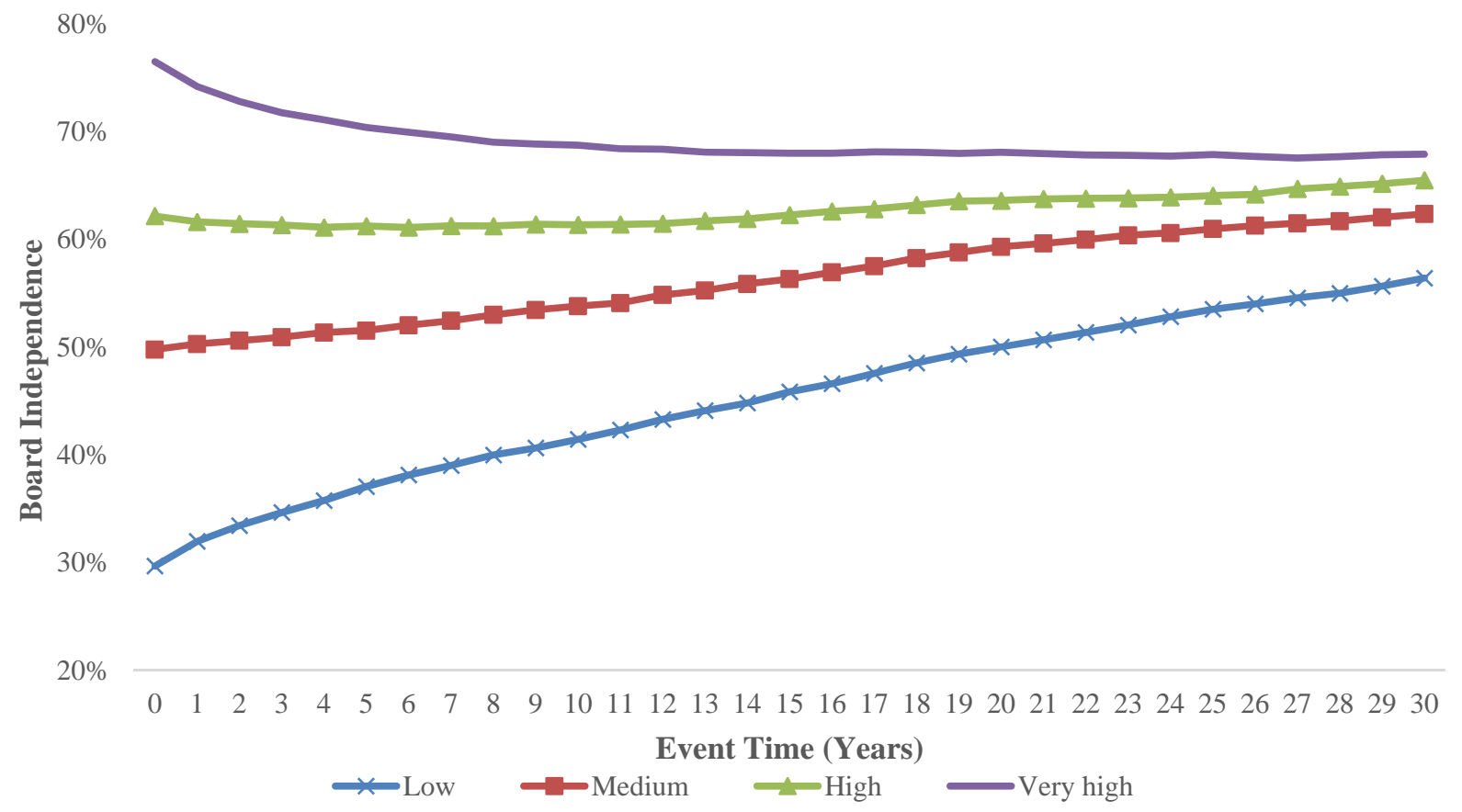




\section{Figure 3: Non-parametric relation between CEO tenure, board independence, and CEO-chair duality}

This figure shows the univariate relation between CEO tenure and board independence (Panel A) and CEO-chair duality (Panel B). Board independence is measured by the ratio of the number of independent directors to all directors (see Table 1 for definition). Firm-years with at least two directors are included in the figures. CEOs with 25 or more years of tenure are shown as $25+$. The straight line is a linear trend.

\section{Panel A: Board independence ratio}

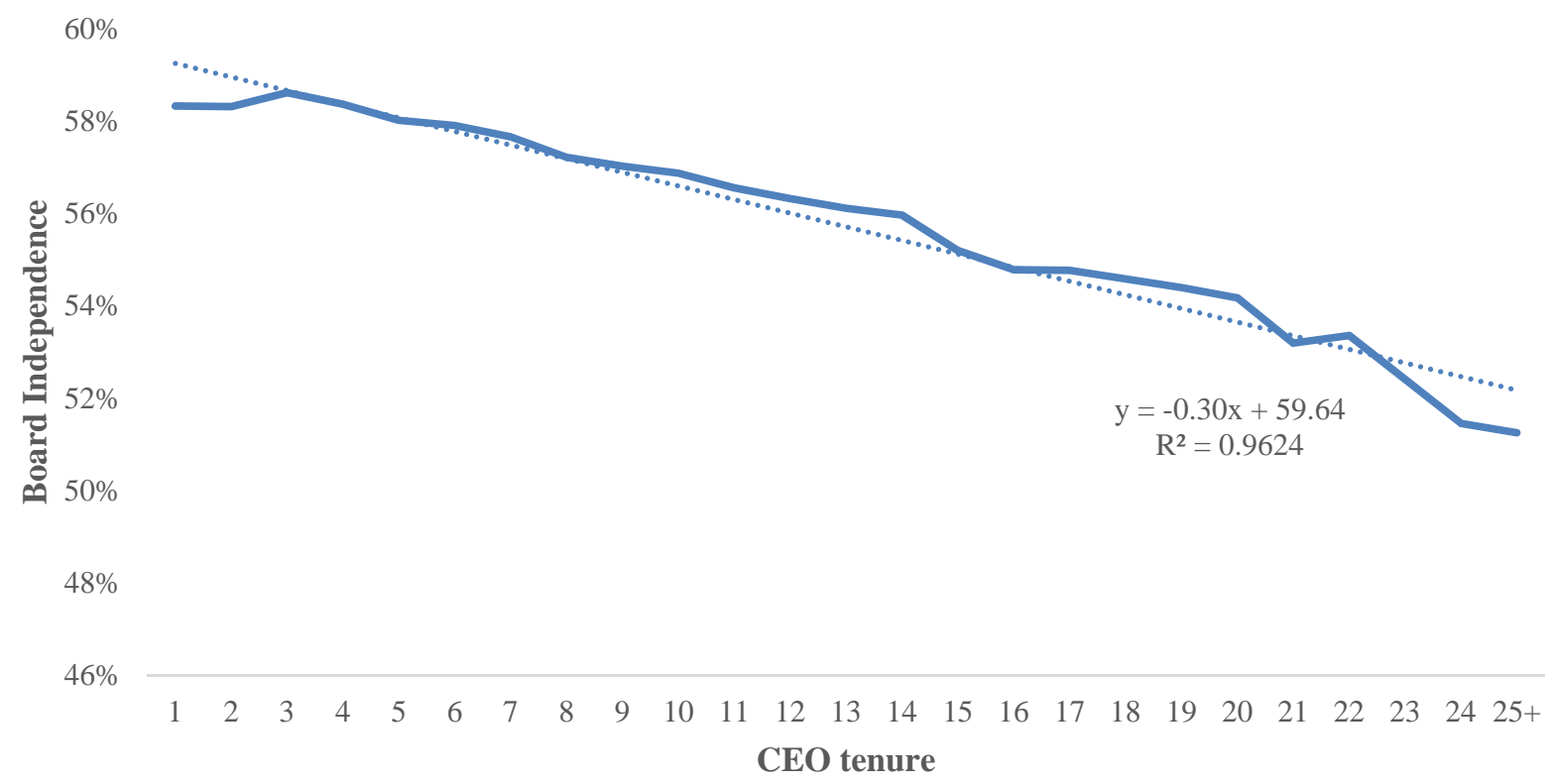

Panel B: CEO-chair duality

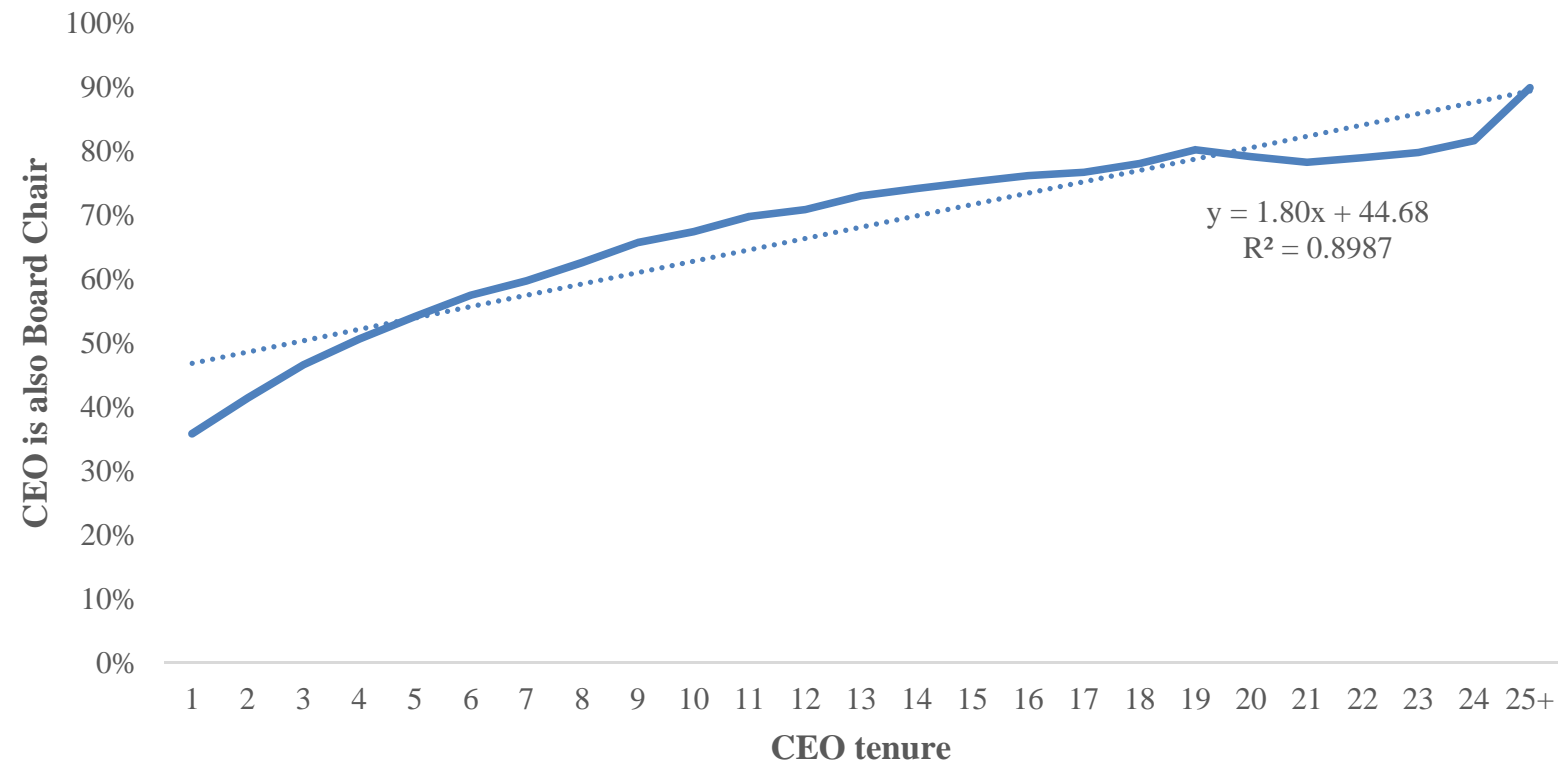




\section{Figure 4: Dynamics of board independence and chair duality following CEO turnover}

This figure presents the dynamics of board independence and chair duality following CEO turnover in year $\mathrm{t}$ (year t1 serves as baseline). The sample includes firm-years from $t-1$ to $t+12$, although any observations from $t+k$ onward are excluded if there is another CEO turnover in year $t+k$. We exclude observations if the previous CEO has less than two years of tenure or the new CEO is replaced within two years. The presented numbers are net of regressionestimated firm and year fixed effects and firm-level controls as in Table 4, Panel A, column 4. In Panel A, the red dashed line shows dynamics of board independence for average new internal CEOs, and the blue solid line shows dynamics of board independence for new internal CEOs whose ultimate tenure is at least 13 years. In Panel B (Panel C), the blue solid line shows dynamics of independence for new internal CEOs whose average industry-adjusted ROA (stock returns) in the first three years is above the median, and the red dashed line shows new internal CEOs whose average ROA (stock returns) is below the median. Panel D presents the dynamics of board chair duality. Panel E presents estimates for new external CEOs.

\section{Panel A: New internal CEOs}

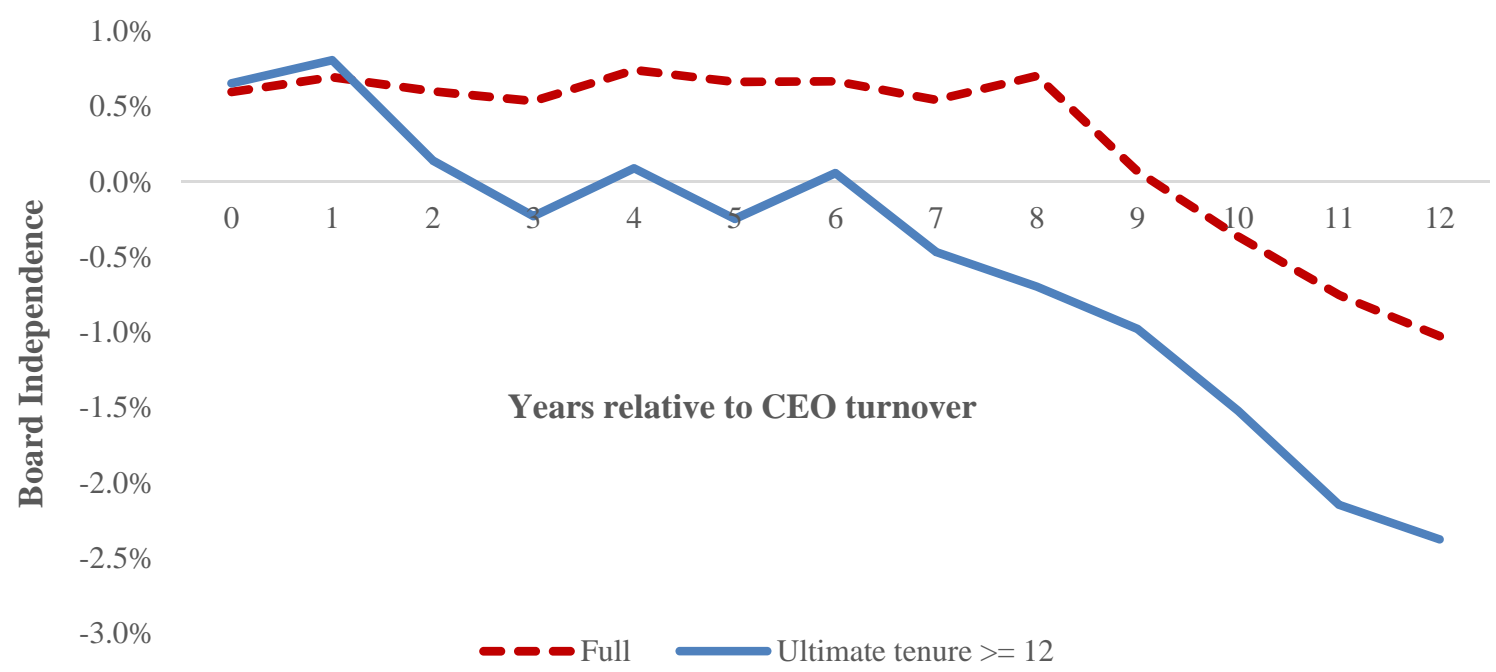

\section{Panel B: New internal CEOs conditional on average ROA over first three years of tenure}

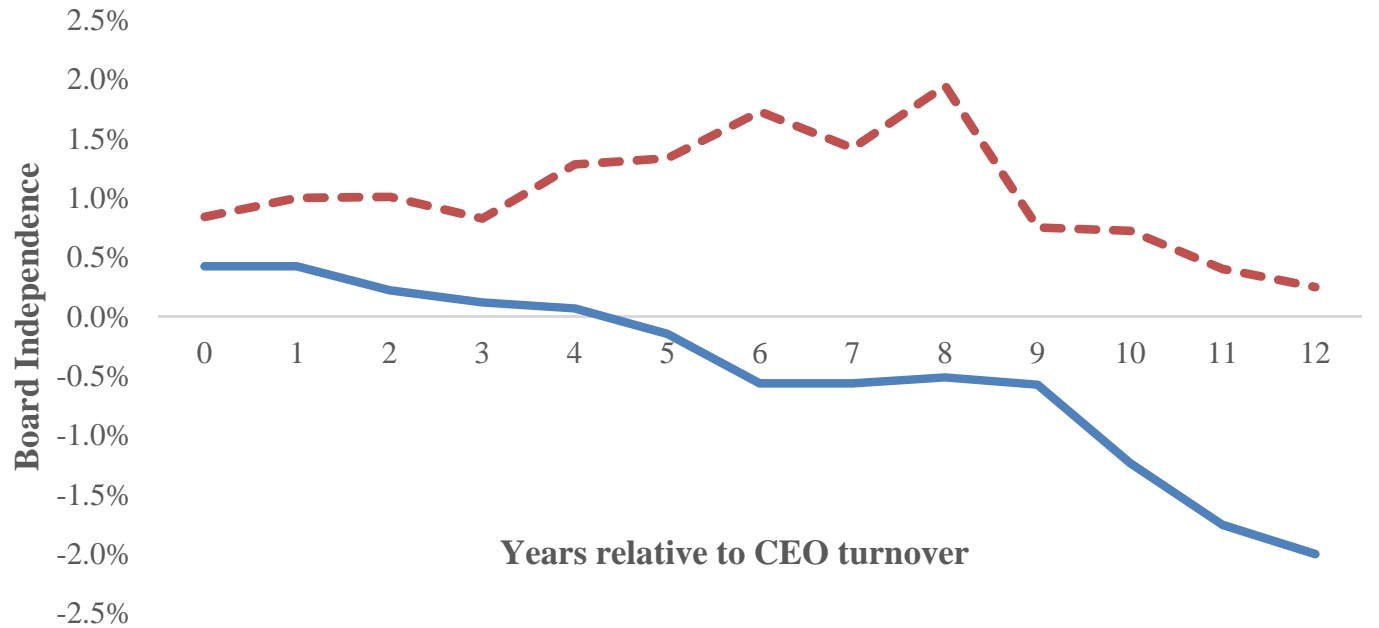


Panel C: New internal CEOs conditional on average excess stock returns over first three years of tenure

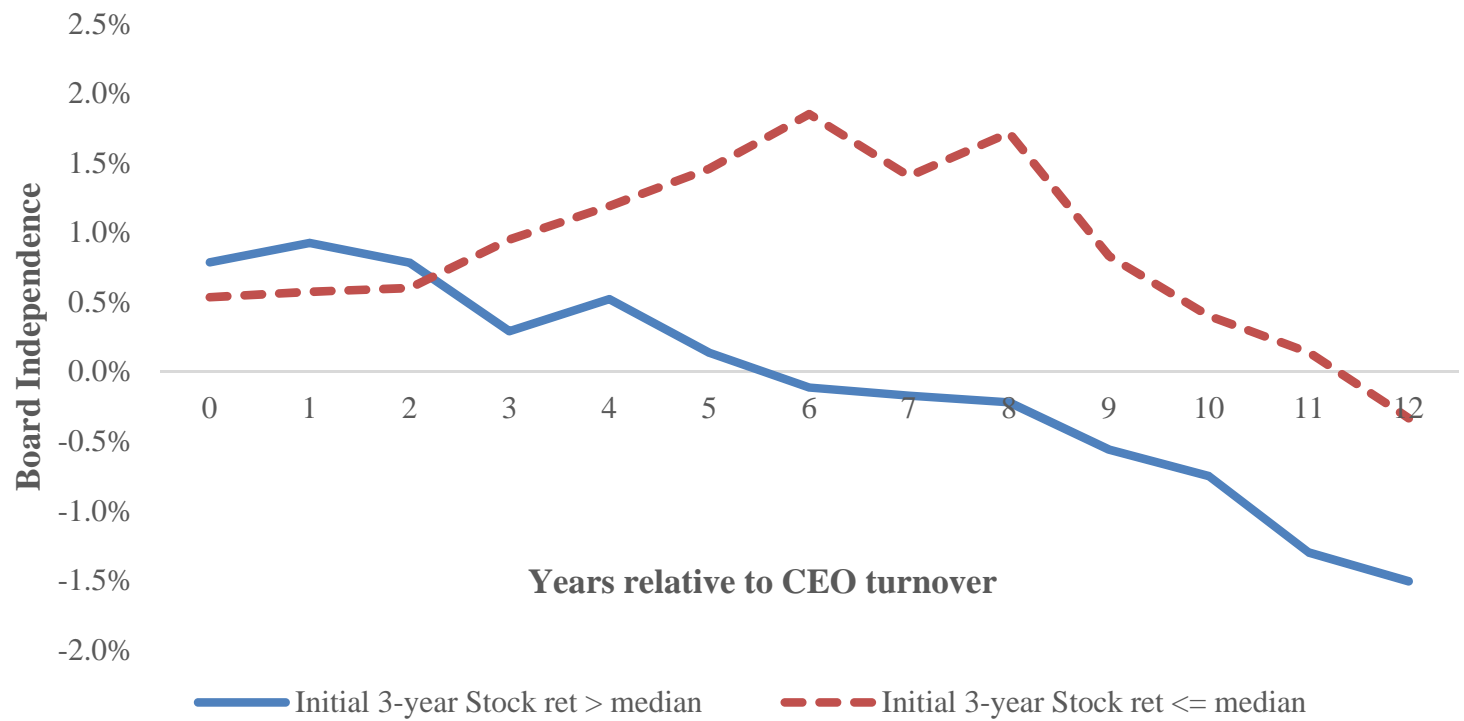

Panel D: New internal CEOs - dual chair titles

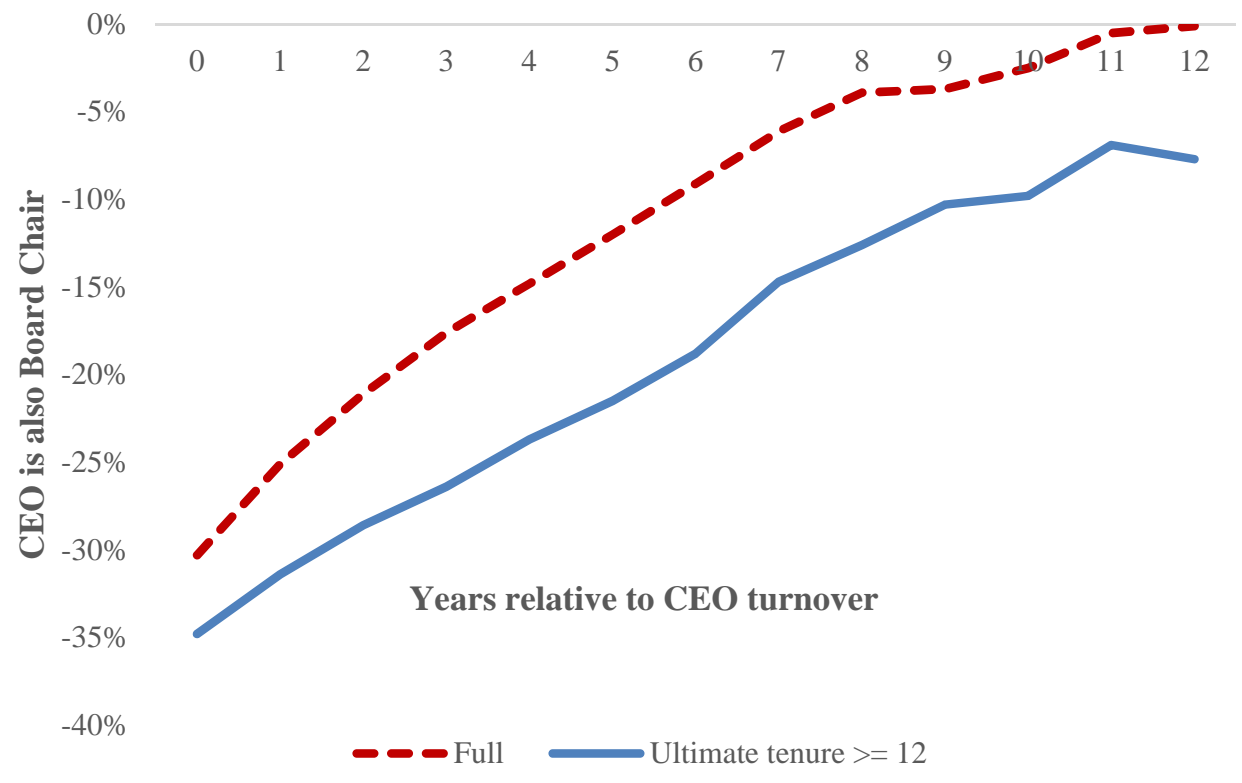




\section{Panel E: New external CEOs}

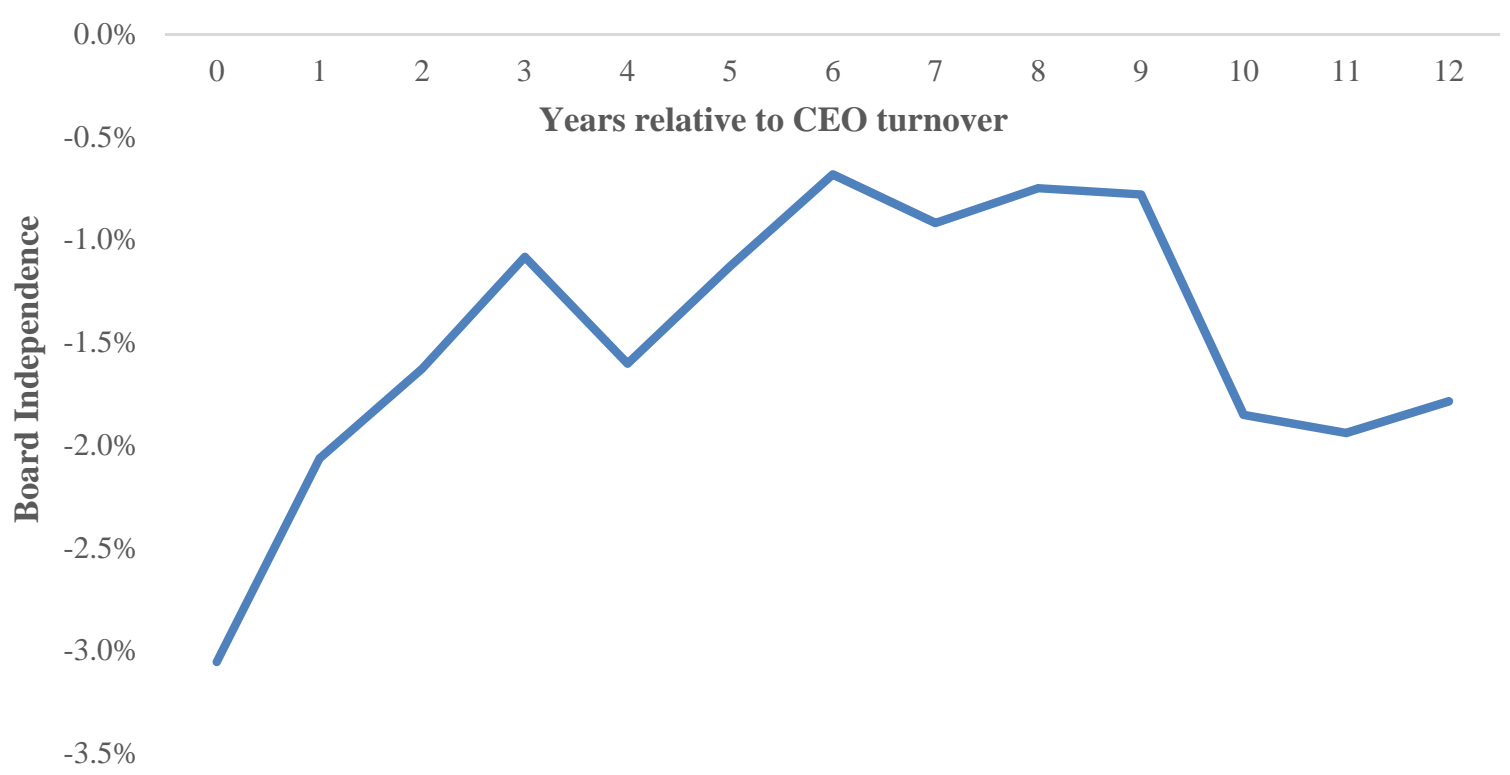


Table 1: Descriptive statistics on CEOs, corporate boards of directors and firms from 1920 to 2011

This table presents summary statistics on corporate boards, CEOs, and firms for U.S. firms from 1920 to 2011. Panel A (B) shows the statistics for board/officer (firm) characteristics. "CEO turnover" equals one if the name of the CEO changes relative to the previous year; "CEO (CFO) [Chair] tenure" is the total number of years during which an individual serves as CEO (CFO) [Chair] of a given firm; "CEO-Chair duality" is an indicator equal to one if the CEO and chair of the board are the same person; "Board size" is the number of directors; "Outsider ratio" is the number of outsider directors scaled by the total number of directors, where outsiders are all directors other than current officers of the firm; "Indep. ratio" is the number of independent directors scaled by the total number of directors, where independent directors are those who are neither current nor previous officers of the firm nor family members of the CEO (identified using last names); "Outside CEO" is an indicator equal to one if the new CEO is not a previous officer of the firm, and zero otherwise. "Total assets" is book assets in 2000 constant million dollars; "Firm age" is the number of years since a firm appears in our database; "ROA" represents return on assets defined as income before taxes scaled by lagged assets; "Tangibility" is PP\&E scaled by assets; "Industry-adj ROA" represents ROA adjusted for the average ROA at the two-digit SIC industry and year level; "Tobin’s q" is book assets minus book equity plus market equity scaled by assets; "Cash/assets” is cash and equivalents scaled by total assets. 2000s* include 2010 and 2011.

Panel A: Board and officer characteristics

\begin{tabular}{|c|c|c|c|c|c|c|c|c|c|c|}
\hline Variable & $\begin{array}{l}\mathrm{N} \text { (firm- } \\
\text { years) }\end{array}$ & $\begin{array}{c}\text { CEO } \\
\text { turnover }\end{array}$ & $\begin{array}{l}\text { CEO } \\
\text { tenure }\end{array}$ & $\begin{array}{l}\text { CFO } \\
\text { tenure }\end{array}$ & $\begin{array}{l}\text { Chair } \\
\text { tenure }\end{array}$ & $\begin{array}{c}\text { CEO-Chair } \\
\text { duality }\end{array}$ & Board size & $\begin{array}{l}\text { Outsider } \\
\text { ratio }\end{array}$ & Indep. ratio & $\begin{array}{l}\text { Outside CEO } \\
\text { (new appt) }\end{array}$ \\
\hline \multicolumn{11}{|c|}{ Panel A: Full Sample (1920-2011) } \\
\hline Mean & 86,946 & 0.119 & 6.28 & 5.08 & 5.87 & 0.416 & 9.89 & 0.643 & 0.575 & 0.324 \\
\hline Median & - & 0.000 & 5.00 & 4.00 & 4.00 & 0.000 & 9.00 & 0.667 & 0.600 & 0.000 \\
\hline STD & - & 0.323 & 5.61 & 4.70 & 5.32 & 0.493 & 3.53 & 0.186 & 0.193 & 0.468 \\
\hline \multicolumn{11}{|c|}{ Panel B: By-decade Mean } \\
\hline 1920s & 3,148 & 0.105 & 4.54 & 4.33 & 3.75 & 0.051 & 11.24 & 0.597 & 0.560 & 0.422 \\
\hline 1930s & 5,125 & 0.087 & 6.61 & 6.33 & 5.30 & 0.084 & 10.81 & 0.571 & 0.520 & 0.365 \\
\hline $1940 s$ & 6,159 & 0.091 & 7.97 & 7.55 & 6.75 & 0.091 & 10.47 & 0.543 & 0.492 & 0.220 \\
\hline $1950 \mathrm{~s}$ & 6,570 & 0.119 & 7.14 & 6.98 & 6.24 & 0.112 & 11.12 & 0.571 & 0.502 & 0.256 \\
\hline $1960 \mathrm{~s}$ & 9,679 & 0.119 & 5.36 & 4.81 & 4.71 & 0.226 & 10.81 & 0.583 & 0.518 & 0.292 \\
\hline $1970 \mathrm{~s}$ & 15,336 & 0.112 & 5.83 & 4.74 & 5.37 & 0.455 & 10.02 & 0.600 & 0.527 & 0.250 \\
\hline 1980s & 12,289 & 0.115 & 7.42 & 5.06 & 6.76 & 0.621 & 9.80 & 0.665 & 0.594 & 0.293 \\
\hline 1990s & 14,548 & 0.142 & 5.81 & 3.88 & 5.84 & 0.639 & 8.70 & 0.698 & 0.632 & 0.396 \\
\hline $2000 s^{*}$ & 14,092 & 0.130 & 6.02 & 4.45 & 6.22 & 0.578 & 8.96 & 0.769 & 0.686 & 0.389 \\
\hline
\end{tabular}


Panel B: Firm characteristics

\begin{tabular}{|c|c|c|c|c|c|c|c|c|}
\hline Variable & $\begin{array}{c}\mathrm{N} \text { (firm- } \\
\text { years) }\end{array}$ & $\begin{array}{c}\text { Total assets } \\
(\$ \text { million in 2000) } \\
\end{array}$ & Firm age & ROA & $\begin{array}{c}\text { Industry-adj } \\
\text { ROA }\end{array}$ & Tangibility & Tobin's q & Cash/assets \\
\hline \multicolumn{9}{|c|}{ Panel A: Full Sample (1920-2011) } \\
\hline Mean & 86,946 & $2,289.14$ & 21.15 & 0.053 & 0.000 & 0.339 & 1.442 & 0.072 \\
\hline Median & - & 375.82 & 16.00 & 0.059 & 0.002 & 0.302 & 1.157 & 0.044 \\
\hline STD & - & $11,897.56$ & 17.71 & 0.095 & 0.087 & 0.203 & 0.965 & 0.081 \\
\hline \multicolumn{9}{|c|}{ Panel B: By-decade Mean } \\
\hline $1920 s$ & 3,148 & 681.27 & 6.43 & 0.076 & -0.001 & 0.443 & 1.263 & 0.062 \\
\hline 1930s & 5,125 & 707.69 & 11.64 & 0.046 & 0.001 & 0.443 & 1.117 & 0.092 \\
\hline 1940s & 6,159 & 736.48 & 18.22 & 0.096 & 0.000 & 0.321 & 1.123 & 0.138 \\
\hline $1950 \mathrm{~s}$ & 6,570 & $1,080.45$ & 24.70 & 0.079 & 0.000 & 0.354 & 1.184 & 0.100 \\
\hline $1960 \mathrm{~s}$ & 9,679 & $1,373.86$ & 22.30 & 0.072 & 0.000 & 0.341 & 1.612 & 0.062 \\
\hline $1970 \mathrm{~s}$ & 15,336 & $1,562.01$ & 21.20 & 0.064 & 0.000 & 0.332 & 1.169 & 0.038 \\
\hline 1980s & 12,289 & 2,227.12 & 24.49 & 0.050 & 0.000 & 0.346 & 1.349 & 0.037 \\
\hline 1990s & 14,548 & $3,026.26$ & 21.61 & 0.031 & 0.000 & 0.329 & 1.735 & 0.068 \\
\hline 2000 s* & 14,092 & $5,178.66$ & 23.30 & 0.022 & 0.001 & 0.292 & 1.822 & 0.095 \\
\hline
\end{tabular}


Table 2: CEO Tenure, and addition and departure of directors

This table presents the number of additions and departures of independent and dependent directors by a given CEO's tenure for internal (Panel A) and external CEOs (Panel B). A CEO is defined as an 'internal' ('external') CEO if she is (is not) a previous officer of the firm. "N" is the number of firm-year observations for each tenure group.

\section{Panel A: Internal CEOs}

\begin{tabular}{cccccc}
\hline \hline $\begin{array}{c}\text { Year rel. to } \\
\text { turnover }\end{array}$ & $\mathbf{N}$ & \multicolumn{2}{c}{ Independent directors } & \multicolumn{2}{c}{ Dependent directors } \\
\cline { 3 - 6 } & & \# Addition & \# Departure & \# Addition & \# Departure \\
\hline-1 & 3,761 & 0.84 & 0.79 & 0.68 & 0.65 \\
0 & 3,761 & 0.98 & 0.95 & 2.46 & 2.60 \\
1 & 3,552 & 0.90 & 0.81 & 0.66 & 0.72 \\
2 & 3,029 & 0.87 & 0.81 & 0.62 & 0.67 \\
3 & 2,670 & 0.83 & 0.80 & 0.63 & 0.69 \\
4 & 2,258 & 0.89 & 0.81 & 0.58 & 0.66 \\
5 & 1,911 & 0.84 & 0.75 & 0.57 & 0.64 \\
6 & 1,664 & 0.84 & 0.75 & 0.55 & 0.61 \\
\hline \hline
\end{tabular}

\section{Panel B: External CEOs}

\begin{tabular}{cccccc}
\hline \hline $\begin{array}{c}\text { Year rel. to } \\
\text { turnover }\end{array}$ & $\mathbf{N}$ & \multicolumn{2}{c}{ Independent directors } & \multicolumn{2}{c}{ Dependent directors } \\
\cline { 3 - 6 } & & \# Addition & \# Departure & \# Addition & \# Departure \\
\hline-1 & 1,232 & 1.03 & 0.93 & 0.57 & 0.63 \\
0 & 1,232 & 1.62 & 1.77 & 2.36 & 2.06 \\
1 & 1,143 & 1.04 & 1.03 & 0.78 & 0.92 \\
2 & 893 & 1.02 & 0.89 & 0.61 & 0.66 \\
3 & 719 & 0.97 & 0.93 & 0.55 & 0.62 \\
4 & 563 & 0.94 & 0.83 & 0.57 & 0.58 \\
5 & 467 & 0.88 & 0.89 & 0.47 & 0.49 \\
6 & 390 & 0.89 & 0.70 & 0.44 & 0.54 \\
\hline \hline
\end{tabular}




\section{Table 3: Persistence of board independence}

This table examines persistence of board independence. "Initial independence ratio" is the board independence ratio for the first available observation of each firm. Panel A uses all firm-years (except for the very first year for each firm), and Panels B and C use the cross-section of firms $T$ years after observing initial board independence $(T=5,10$, or 20). Panel D sorts firms into board independence ratio quartiles in a given year, and follows them over the next 10 years. Panel $\mathrm{E}$ reports $\mathrm{R}^{2}$ 's from panel regressions with various layers of fixed effects. ${ }^{*},{ }^{* *}$, and ${ }^{* * *}$ represent results significant at the 10,5 , and $1 \%$ levels, respectively.

\begin{tabular}{|c|c|c|c|}
\hline Dep. Var.: & \multicolumn{3}{|c|}{ \# Indept. / \# Total Directors (Independence ratio) } \\
\hline & (1) & (2) & (3) \\
\hline \multicolumn{4}{|c|}{ Panel A: Full sample } \\
\hline Initial independence ratio & $\begin{array}{c}9.411^{* * *} \\
(38.96)\end{array}$ & $\begin{array}{c}8.574 * * * \\
(36.98)\end{array}$ & $\begin{array}{c}8.140 * * * \\
(35.39)\end{array}$ \\
\hline CEO tenure & $\begin{array}{c}-1.300 * * * \\
(-7.66)\end{array}$ & $\begin{array}{c}-1.195 * * * \\
(-7.46)\end{array}$ & $\begin{array}{c}-0.943 * * * \\
(-6.12)\end{array}$ \\
\hline Firm age & $\begin{array}{c}4.109 * * * \\
(18.95)\end{array}$ & $\begin{array}{c}3.666 * * * \\
(17.71)\end{array}$ & $\begin{array}{c}2.492 * * * \\
(11.37)\end{array}$ \\
\hline $\log ($ board size $)$ & $\begin{array}{l}- \\
-\end{array}$ & $\begin{array}{l}- \\
-\end{array}$ & $\begin{array}{c}2.966 * * * \\
(13.49)\end{array}$ \\
\hline $\log$ (assets) & $\begin{array}{l}- \\
-\end{array}$ & $\begin{array}{l}- \\
-\end{array}$ & $\begin{array}{l}0.354 \\
(1.21)\end{array}$ \\
\hline $\mathrm{q}$ & - & - & $\begin{array}{l}-0.010 \\
(-0.07)\end{array}$ \\
\hline ROA & $\begin{array}{l}- \\
-\end{array}$ & $\begin{array}{l}- \\
-\end{array}$ & $\begin{array}{c}-0.316^{* * *} \\
(-3.01)\end{array}$ \\
\hline Tangibility & $\begin{array}{l}- \\
-\end{array}$ & $\begin{array}{l}- \\
-\end{array}$ & $\begin{array}{c}0.589 * * * \\
(3.35)\end{array}$ \\
\hline Year fixed effects & & $\mathrm{Y}$ & $\mathrm{Y}$ \\
\hline $\begin{array}{l}\mathrm{R}^{2} \\
\mathrm{~N}\end{array}$ & $\begin{array}{r}0.274 \\
80761 \\
\end{array}$ & $\begin{array}{r}0.345 \\
80761 \\
\end{array}$ & $\begin{array}{r}0.368 \\
80761 \\
\end{array}$ \\
\hline \multicolumn{4}{|c|}{ Panel B: Cross-Section } \\
\hline Timing relative to initial year: & $\mathbf{t}+5$ & $\mathbf{t}+\mathbf{1 0}$ & $\mathbf{t}+\mathbf{2 0}$ \\
\hline Initial independence ratio & $\begin{array}{c}10.956^{* * *} \\
(37.74)\end{array}$ & $\begin{array}{c}8.899 * * * \\
(26.81)\end{array}$ & $\begin{array}{c}6.760^{* * *} \\
(14.23)\end{array}$ \\
\hline CEO tenure & $\begin{array}{l}-0.013 \\
(-0.03)\end{array}$ & $\begin{array}{c}-1.325^{* * *} \\
(-3.44)\end{array}$ & $\begin{array}{c}-1.049 * * * \\
(-2.91)\end{array}$ \\
\hline Firm-level controls & $\mathrm{Y}$ & $\mathrm{Y}$ & $\mathrm{Y}$ \\
\hline Year fixed effects & $\mathrm{Y}$ & $\mathrm{Y}$ & $\mathrm{Y}$ \\
\hline $\mathrm{R}^{2}$ & 0.476 & 0.412 & 0.324 \\
\hline $\mathrm{N}$ & 3633 & 2644 & 1370 \\
\hline \multicolumn{4}{|c|}{ Panel C: Cross-section (with no controls or fixed effects) } \\
\hline Timing relative to initial year: & $t+5$ & $t+10$ & $t+20$ \\
\hline Initial independence ratio & $\begin{array}{c}12.612^{* * *} \\
(46.70)\end{array}$ & $\begin{array}{c}10.640 * * * \\
(33.19)\end{array}$ & $\begin{array}{c}7.631^{* * * *} \\
(15.59)\end{array}$ \\
\hline $\begin{array}{l}\text { Firm-level controls } \\
\text { Year fixed effects }\end{array}$ & & & \\
\hline $\begin{array}{l}\mathrm{R}^{2} \\
\mathrm{~N}\end{array}$ & $\begin{array}{l}0.414 \\
3633\end{array}$ & $\begin{array}{l}0.321 \\
2644\end{array}$ & $\begin{array}{l}0.159 \\
1370\end{array}$ \\
\hline
\end{tabular}


Panel D: Transition matrix for board independence

\begin{tabular}{|c|c|c|c|c|c|c|c|c|c|c|}
\hline Year & 1 & 2 & 3 & 4 & 5 & 6 & 7 & 8 & 9 & 10 \\
\hline \multicolumn{11}{|c|}{ Year 0 Quartile = 1} \\
\hline \% quartile 1 & $82.5 \%$ & $75.7 \%$ & $71.0 \%$ & $67.9 \%$ & $65.1 \%$ & $63.0 \%$ & $61.7 \%$ & $60.2 \%$ & $59.2 \%$ & $58.3 \%$ \\
\hline \% quartile 2 & $14.1 \%$ & $18.6 \%$ & $21.0 \%$ & $22.4 \%$ & $23.6 \%$ & $24.1 \%$ & $24.4 \%$ & $24.6 \%$ & $24.3 \%$ & $24.4 \%$ \\
\hline \% quartile 3 & $2.5 \%$ & $4.3 \%$ & $6.0 \%$ & $7.4 \%$ & $8.4 \%$ & $9.5 \%$ & $10.2 \%$ & $11.0 \%$ & $12.1 \%$ & $12.3 \%$ \\
\hline \% quartile 4 & $0.9 \%$ & $1.4 \%$ & $2.0 \%$ & $2.3 \%$ & $2.9 \%$ & $3.4 \%$ & $3.8 \%$ & $4.2 \%$ & $4.4 \%$ & $5.0 \%$ \\
\hline \multicolumn{11}{|c|}{ Year 0 Quartile = 2} \\
\hline \% quartile 1 & $15.4 \%$ & $19.9 \%$ & $22.5 \%$ & $24.2 \%$ & $25.6 \%$ & $26.9 \%$ & $27.3 \%$ & $27.7 \%$ & $28.4 \%$ & $28.6 \%$ \\
\hline \% quartile 2 & $64.2 \%$ & $53.4 \%$ & $47.4 \%$ & $43.2 \%$ & $39.9 \%$ & $37.7 \%$ & $36.1 \%$ & $35.0 \%$ & $34.3 \%$ & $33.5 \%$ \\
\hline \% quartile 3 & $17.5 \%$ & $21.7 \%$ & $23.4 \%$ & $24.6 \%$ & $25.4 \%$ & $25.3 \%$ & $25.7 \%$ & $25.8 \%$ & $25.5 \%$ & $25.9 \%$ \\
\hline \% quartile 4 & $2.9 \%$ & $5.0 \%$ & $6.7 \%$ & $8.0 \%$ & $9.1 \%$ & $10.1 \%$ & $10.8 \%$ & $11.5 \%$ & $11.7 \%$ & $12.0 \%$ \\
\hline \multicolumn{11}{|c|}{ Year 0 Quartile = 3} \\
\hline \% quartile 1 & $2.6 \%$ & $4.8 \%$ & $6.4 \%$ & $7.9 \%$ & $9.4 \%$ & $10.4 \%$ & $11.6 \%$ & $12.4 \%$ & $13.1 \%$ & $13.8 \%$ \\
\hline \% quartile 2 & $17.1 \%$ & $20.9 \%$ & $22.9 \%$ & $23.8 \%$ & $24.6 \%$ & $25.1 \%$ & $24.9 \%$ & $25.7 \%$ & $25.9 \%$ & $26.2 \%$ \\
\hline \% quartile 3 & $63.9 \%$ & $53.1 \%$ & $46.7 \%$ & $42.9 \%$ & $39.8 \%$ & $37.9 \%$ & $36.3 \%$ & $34.5 \%$ & $33.8 \%$ & $33.0 \%$ \\
\hline \% quartile 4 & $16.4 \%$ & $21.2 \%$ & $24.0 \%$ & $25.5 \%$ & $26.2 \%$ & $26.6 \%$ & $27.1 \%$ & $27.5 \%$ & $27.1 \%$ & $26.9 \%$ \\
\hline \multicolumn{11}{|c|}{ Year 0 Quartile = 4} \\
\hline \% quartile 1 & $0.8 \%$ & $1.6 \%$ & $2.5 \%$ & $3.2 \%$ & $3.9 \%$ & $4.5 \%$ & $5.0 \%$ & $5.7 \%$ & $6.3 \%$ & $7.2 \%$ \\
\hline \% quartile 2 & $3.1 \%$ & $5.6 \%$ & $7.4 \%$ & $9.3 \%$ & $10.6 \%$ & $11.9 \%$ & $13.3 \%$ & $14.3 \%$ & $15.2 \%$ & $15.8 \%$ \\
\hline \% quartile 3 & $18.4 \%$ & $23.8 \%$ & $26.9 \%$ & $28.6 \%$ & $29.8 \%$ & $30.4 \%$ & $31.0 \%$ & $31.5 \%$ & $31.2 \%$ & $31.1 \%$ \\
\hline \% quartile 4 & $77.7 \%$ & $69.1 \%$ & $63.2 \%$ & $58.9 \%$ & $55.7 \%$ & $53.2 \%$ & $50.7 \%$ & $48.6 \%$ & $47.3 \%$ & $45.8 \%$ \\
\hline
\end{tabular}

\section{Panel E: R-squared of fixed-effect regressions}

\begin{tabular}{|c|c|c|c|c|c|c|c|}
\hline \multirow[t]{2}{*}{ Dep. Var. } & \multicolumn{7}{|c|}{ Independence ratio } \\
\hline & $(1)$ & (2) & (3) & $(4)$ & (5) & (6) & (7) \\
\hline \multicolumn{8}{|c|}{ Full Sample } \\
\hline Firm-decade fixed effects & & & $\mathrm{Y}$ & & & & $\mathrm{Y}$ \\
\hline Firm-3-decade fixed effects & & $\mathrm{Y}$ & & & & $\mathrm{Y}$ & \\
\hline Firm fixed effects & $\mathrm{Y}$ & & & & $\mathrm{Y}$ & & \\
\hline Year fixed effects & & & & $\mathrm{Y}$ & $\mathrm{Y}$ & $\mathrm{Y}$ & $\mathrm{Y}$ \\
\hline $\mathrm{R}^{2}$ & 0.568 & 0.706 & 0.819 & 0.129 & 0.645 & 0.725 & 0.824 \\
\hline $\mathrm{N}$ & 86946 & 86946 & 86946 & 86946 & 86946 & 86946 & 86946 \\
\hline \multicolumn{8}{|c|}{ Survival Sample (at least 20 years) } \\
\hline $\mathrm{R}^{2}$ & 0.518 & 0.694 & 0.823 & 0.156 & 0.653 & 0.728 & 0.832 \\
\hline $\mathrm{N}$ & 27228 & 27228 & 27228 & 27228 & 27228 & 27228 & 27228 \\
\hline
\end{tabular}




\section{Table 4: CEO tenure and board independence}

This table presents the relations between the CEO's tenure (Panel A) or firm performance (Panel B), and board independence. Column 5 of Panel A measures CEO tenure effects using the instrumental variable approach of Altonji and Shakotko (1987), which at each point in time reflects the proportion of a given CEO's ultimate tenure. Firms with only one reported director are excluded from the sample. Column 5, which employs an instrumental variable with firm fixed effects, shows within-firm R-squared, whereas the other columns show total R-squared. All standard errors are adjusted for sample clustering at the firm level. *, **, and *** represent results significant at the 10,5 , and $1 \%$ levels, respectively.

\section{Panel A: CEO tenure and board independence}

\begin{tabular}{|c|c|c|c|c|c|c|}
\hline \multirow[t]{2}{*}{ Dep. Var.: } & \multicolumn{6}{|c|}{ Independence ratio } \\
\hline & (1) & (2) & (3) & (4) & (5) & (6) \\
\hline Sample period: & 1996-2011 & 1996-2011 & Full & Full & Full & Full \\
\hline Model: & OLS & OLS & OLS & OLS & AS (1987) IV & OLS \\
\hline \multirow[t]{2}{*}{ CEO tenure } & $-0.306 * * *$ & -0.016 & $-0.146 * * *$ & $-0.150 * * *$ & $-0.170 * * *$ & $-0.247 * * *$ \\
\hline & $(-7.04)$ & $(-0.45)$ & $(-6.74)$ & $(-6.87)$ & $(-8.63)$ & $(-8.40)$ \\
\hline \multirow[t]{2}{*}{ Firm age } & $0.041 * * *$ & - & - & - & - & $0.064 * * *$ \\
\hline & $(3.02)$ & - & - & - & - & $(5.34)$ \\
\hline \multirow[t]{2}{*}{$\log ($ board size $)$} & $9.663 * * *$ & $9.611^{* * *}$ & - & $9.966 * * *$ & $9.971 * * *$ & $11.257 * * *$ \\
\hline & $(9.71)$ & $(9.10)$ & - & (14.89) & $(14.91)$ & $(15.00)$ \\
\hline \multirow[t]{2}{*}{$\log$ (assets) } & $1.621 * * *$ & 0.001 & - & -0.280 & -0.271 & $0.356 * *$ \\
\hline & $(9.46)$ & $(0.00)$ & - & $(-1.05)$ & $(-1.01)$ & $(2.12)$ \\
\hline \multirow[t]{2}{*}{$\mathrm{q}$} & $0.988 * * *$ & -0.003 & - & 0.023 & 0.020 & 0.043 \\
\hline & $(5.35)$ & $(-0.01)$ & - & $(0.14)$ & $(0.12)$ & $(0.24)$ \\
\hline \multirow[t]{2}{*}{ ROA (ind-adj) } & $-4.912 * * *$ & $-4.657 * * *$ & - & $-2.312 * *$ & $-2.283^{* *}$ & $-4.878 * * *$ \\
\hline & $(-3.00)$ & $(-3.62)$ & - & $(-2.04)$ & $(-2.02)$ & $(-3.48)$ \\
\hline \multirow[t]{2}{*}{ Tangibility } & $1.912 *$ & 1.487 & - & $2.479 *$ & $2.484 *$ & $5.120 * * *$ \\
\hline & $(1.65)$ & $(0.82)$ & - & $(1.88)$ & $(1.88)$ & (5.19) \\
\hline Firm fixed effects & & $\mathrm{Y}$ & $\mathrm{Y}$ & $\mathrm{Y}$ & $\mathrm{Y}$ & \\
\hline Year fixed effects & $\mathrm{Y}$ & $\mathrm{Y}$ & $\mathrm{Y}$ & $\mathrm{Y}$ & $\mathrm{Y}$ & $\mathrm{Y}$ \\
\hline $\mathrm{R}^{2}$ & 0.164 & 0.707 & 0.646 & 0.656 & 0.202 & 0.200 \\
\hline $\mathrm{N}$ & 20469 & 20469 & 86946 & 86946 & 86375 & 86946 \\
\hline
\end{tabular}


Panel B: Firm performance and board independence

\begin{tabular}{|c|c|c|c|c|c|c|}
\hline \multirow[t]{2}{*}{$\begin{array}{l}\text { Dep. Var. } \\
\text { Sample: }\end{array}$} & \multicolumn{6}{|c|}{$\begin{array}{l}\Delta \text { Independence ratio } \\
\text { Non-turnover }\end{array}$} \\
\hline & (1) & (2) & (3) & (4) & (5) & (6) \\
\hline Performance measure: & \multicolumn{3}{|c|}{$\begin{array}{c}\text { ROA } \\
\text { (recent } 3 \text { years) }\end{array}$} & \multicolumn{3}{|c|}{$\begin{array}{c}\text { Stock return } \\
\text { (recent } 3 \text { years) }\end{array}$} \\
\hline Performance (ind-adj) & $\begin{array}{c}-1.319 * * * \\
(-2.76)\end{array}$ & $\begin{array}{c}-3.045^{* * *} \\
(-3.74)\end{array}$ & $\begin{array}{c}-3.263 * * * \\
(-2.77)\end{array}$ & $\begin{array}{c}-5.222 * * * \\
(-2.68)\end{array}$ & $\begin{array}{c}-5.504^{* *} \\
(-2.51)\end{array}$ & $\begin{array}{l}-3.380 \\
(-1.39)\end{array}$ \\
\hline$\Delta \log ($ board size) & $\begin{array}{c}14.883^{* * * *} \\
(17.97)\end{array}$ & $\begin{array}{c}14.826^{* * *} \\
(17.14)\end{array}$ & $\begin{array}{c}14.916^{* * *} \\
(16.22)\end{array}$ & $\begin{array}{c}14.990 * * * \\
(18.00)\end{array}$ & $\begin{array}{c}14.931^{* * *} \\
(17.17)\end{array}$ & $\begin{array}{c}14.996 * * * \\
(16.20)\end{array}$ \\
\hline$\Delta \log$ (assets) & $\begin{array}{c}-0.343^{*} \\
(-1.79)\end{array}$ & $\begin{array}{l}-0.289 \\
(-1.33)\end{array}$ & $\begin{array}{l}-0.238 \\
(-1.02)\end{array}$ & $\begin{array}{l}-0.348^{*} \\
(-1.83)\end{array}$ & $\begin{array}{c}-0.365^{*} \\
(-1.70)\end{array}$ & $\begin{array}{l}-0.306 \\
(-1.35)\end{array}$ \\
\hline$\Delta$ Tangibility & $\begin{array}{l}-0.637 \\
(-0.90)\end{array}$ & $\begin{array}{l}-0.285 \\
(-0.39)\end{array}$ & $\begin{array}{l}-0.401 \\
(-0.51)\end{array}$ & $\begin{array}{l}-0.793 \\
(-1.10)\end{array}$ & $\begin{array}{l}-0.520 \\
(-0.69)\end{array}$ & $\begin{array}{l}-0.594 \\
(-0.75)\end{array}$ \\
\hline Firm fixed effects & & $\mathrm{Y}$ & & & $\mathrm{Y}$ & \\
\hline Firm-CEO fixed effects & & & $\mathrm{Y}$ & & & $\mathrm{Y}$ \\
\hline Year fixed effects & $\mathrm{Y}$ & $\mathrm{Y}$ & $\mathrm{Y}$ & $\mathrm{Y}$ & $\mathrm{Y}$ & $\mathrm{Y}$ \\
\hline $\mathrm{R}^{2}$ & 0.089 & 0.153 & 0.239 & 0.091 & 0.155 & 0.240 \\
\hline $\mathrm{N}$ & 66003 & 66003 & 66003 & 64998 & 64998 & 64998 \\
\hline
\end{tabular}




\section{Table 5: CEO tenure, chair duality and compensation}

This table presents the relations between the CEO's tenure and CEO-chair duality (columns 1-2) or total current compensation including salary and bonus (columns 3-4). Columns 2 and 4 measure CEO tenure effects using the instrumental variable approach of Altonji and Shakotko (1987), which at each point in time reflects the proportion of a given CEO's ultimate tenure. Firms with only one reported director are excluded from the sample. Firm and year fixed effects are included in all specifications. All standard errors are adjusted for sample clustering at the firm level. $*$, **, and $* * *$ represent results significant at the 10,5 , and $1 \%$ levels, respectively.

\begin{tabular}{lcccc}
\hline \hline \multirow{2}{*}{ Dep. Var. } & \multicolumn{2}{c}{1 (Chair duality) } & \multicolumn{2}{c}{ Log(Compensation) } \\
\hline \multirow{2}{*}{ Model: } & $(1)$ & $(2)$ & $(3)$ & $(4)$ \\
\hline CEO tenure & OLS & AS-IV & OLS & AS-IV \\
& $2.180^{* * *}$ & $2.382^{* * *}$ & $0.024^{* * *}$ & $0.025^{* * *}$ \\
log(board size) & $(26.38)$ & $(30.04)$ & $(5.73)$ & $(9.11)$ \\
& $-11.369^{* * *}$ & $-11.406^{* * *}$ & 0.039 & 0.042 \\
log(assets) & $(-7.93)$ & $(-7.96)$ & $(0.47)$ & $(0.52)$ \\
& $2.998^{* * *}$ & $2.906^{* * *}$ & $0.293^{* * *}$ & $0.293^{* * *}$ \\
q & $(4.55)$ & $(4.40)$ & $(7.56)$ & $(7.86)$ \\
& $0.750^{*}$ & $0.752^{*}$ & 0.007 & 0.007 \\
ROA (ind-adj) & $(1.77)$ & $(1.77)$ & $(0.19)$ & $(0.20)$ \\
& 1.168 & 0.681 & $1.463^{* * *}$ & $1.419 * * *$ \\
Stock return (ind-adj) & $(0.36)$ & $(0.21)$ & $(4.37)$ & $(4.53)$ \\
& - & - & $2.564^{* * *}$ & $2.573^{* * *}$ \\
Tangibility & - & - & $(4.35)$ & $(4.42)$ \\
& 4.524 & 4.403 & -0.110 & -0.118 \\
Firm fixed effects & $(1.24)$ & $(1.20)$ & $(-0.69)$ & $(-0.74)$ \\
Year fixed effects & $\mathrm{Y}$ & $\mathrm{Y}$ & $\mathrm{Y}$ & $\mathrm{Y}$ \\
$\mathrm{R}^{2}$ & $\mathrm{Y}$ & $\mathrm{Y}$ & $\mathrm{Y}$ & $\mathrm{Y}$ \\
$\mathrm{N}$ & 0.534 & 0.197 & 0.880 & 0.832 \\
\hline \hline
\end{tabular}




\section{Table 6: Regulations, CEO tenure, and governance outcomes}

This table examines the effect of the CEO's tenure on board independence, CEO-chair duality, and compensation for years before and after 2002 when new regulations began to require firms to maintain majority independent boards. "Post 2002" is an indicator variable equal to one for years equal to or after 2002, and zero for years before 2002. The dependent variables are independence ratio, an indicator for CEO-chair duality, and the log of the CEO's current compensation in columns 1, 2, and 3. Firms with only one reported director are excluded from the sample. Firm $\times$ post-2002 period and year fixed effects are used throughout the table. All standard errors are adjusted for sample clustering at the firm level. *, **, and *** represent results significant at the 10,5 , and $1 \%$ levels, respectively.

\begin{tabular}{lccc}
\hline \hline Dep. Var. & Independence ratio & 1 (Chair duality) & Log (Compensation) \\
\hline CEO tenure & $(1)$ & $(2)$ & $(3)$ \\
& $-0.155^{* * *}$ & $2.088^{* * *}$ & $0.023^{* * *}$ \\
CEO tenure $\times$ Post 2002 & $(-6.84)$ & $(23.69)$ & $(5.46)$ \\
& $0.140^{* * *}$ & $1.309^{* * *}$ & -0.008 \\
$\log$ (board size) & $(3.11)$ & $(5.33)$ & $(-0.48)$ \\
& $10.483^{* * *}$ & $-10.119^{* * *}$ & 0.034 \\
$\log ($ assets) & $(15.49)$ & $(-7.05)$ & $(0.39)$ \\
& -0.453 & $2.333^{* * *}$ & $0.292^{* * *}$ \\
$\mathrm{q}$ & $(-1.64)$ & $(3.26)$ & $(6.62)$ \\
& -0.090 & $0.728^{*}$ & 0.021 \\
ROA (ind-adj) & $(-0.58)$ & $(1.72)$ & $(0.58)$ \\
& -1.219 & 0.142 & $1.216^{* * *}$ \\
Stock return (ind-adj) & $(-1.10)$ & $(0.04)$ & $(4.77)$ \\
& - & - & $2.682^{* * *}$ \\
Tangibility & - & - & $(4.27)$ \\
& $2.863^{* *}$ & 4.741 & -0.134 \\
Firm $\times$ period fixed effects & $(2.21)$ & $(1.27)$ & $(-0.79)$ \\
Year fixed effects & $\mathrm{Y}$ & $\mathrm{Y}$ & $\mathrm{Y}$ \\
$\mathrm{R}^{2}$ & $\mathrm{Y}$ & $\mathrm{Y}$ & $\mathrm{Y}$ \\
$\mathrm{N}$ & 0.684 & 0.568 & 0.898 \\
\hline \hline
\end{tabular}




\section{Table 7: CEO turnover conditional on firm performance and CEO power}

This table examines how CEO power affects the sensitivity of CEO turnover to firm performance proxied by changes in return on assets (ROA) defined as income before taxes (as 'IB' in Compustat) scaled by lagged assets (Panel A) and average excess stock return for the 12-month period prior to the fiscal year ending date (Panel B). Both panels use contemporaneous ( $\mathrm{t}$ ) and lagged ( $\mathrm{t}-1$ ) measures of performance. All accounting variables are from Moody's Industrial Manual or Compustat and stock returns are from CRSP. Linear probability models (i.e., OLS) with firm and year fixed effects are used throughout the table, although results largely hold up in logit models with firm fixed effects (i.e., conditional logit). As a proxy for CEO power, the columns from left to right use an indicator "Low independence" that is equal to one if the board independence ratio is in the first quartile, an indicator for CEO-chair duality, an indicator for average ROA during the CEO's first three years in the fourth quartile, an indicator for average stock returns during the CEO's first three years in the fourth quartile, and an indicator for CEO tenure in the fourth quartile. Column 2 uses data starting in 1960, to coincide with the timing of when there is less ambiguity in whether the CEO is dual board chair. Columns 3 and 4 include only observations for CEOs with at least four years of tenure, to ensure that average performance during the CEO's first three years is well measured. All standard errors are adjusted for sample clustering at the firm level. *, **, and ${ }^{* * *}$ represent results significant at the 10,5 , and $1 \%$ levels, respectively.

\section{Panel A: Change in ROA as performance measure}

\begin{tabular}{lccccc}
\hline \hline \multirow{2}{*}{ Dep. Var. - Model } & \multicolumn{5}{c}{ CEO Turnover [t] $\{0,1\}-$ OLS } \\
\cline { 2 - 6 } Sample: & \multicolumn{5}{c}{$1926-2011$} \\
Power proxy: & $1926-2011$ & $1960-2011$ & \multicolumn{2}{c}{ Tenure $\geq 4$} & $1926-2011$ \\
\cline { 2 - 6 } & Low indep. & Chair duality & High ROA & High return & Long tenure \\
\cline { 2 - 6 }$\Delta$ ROA [t] & $-0.293^{* * *}$ & $-0.450^{* * *}$ & $-0.539^{* * *}$ & $-0.381^{* * *}$ & $-0.268^{* * *}$ \\
& $(-10.17)$ & $(-8.11)$ & $(-12.66)$ & $(-8.77)$ & $(-8.95)$ \\
$\Delta$ ROA [t] $\times$ Power & $0.188^{* * *}$ & $0.309^{* * *}$ & $1.360^{* * *}$ & $0.573^{* * *}$ & 0.048 \\
& $(3.08)$ & $(4.85)$ & $(17.08)$ & $(7.48)$ & $(0.85)$ \\
$\Delta$ ROA [t-1] & $-0.192^{* * *}$ & $-0.220^{* * *}$ & $-0.427^{* * *}$ & $-0.249^{* * *}$ & $-0.157^{* * *}$ \\
& $(-6.78)$ & $(-4.11)$ & $(-10.26)$ & $(-6.06)$ & $(-5.45)$ \\
$\Delta$ ROA [t-1] $\times$ Power & $0.124^{* *}$ & 0.097 & $0.856^{* * *}$ & $0.145^{*}$ & -0.030 \\
& $(2.25)$ & $(1.60)$ & $(11.70)$ & $(1.89)$ & $(-0.57)$ \\
Power & -0.004 & $-0.214^{* * *}$ & $-0.104^{* * *}$ & $-0.031^{* * *}$ & $0.066^{* * *}$ \\
& $(-0.77)$ & $(-36.04)$ & $(-10.81)$ & $(-3.23)$ & $(20.04)$ \\
CEO tenure & $0.007^{* * *}$ & $0.012^{* * *}$ & $0.012^{* * *}$ & $0.014^{* * *}$ & - \\
& $(22.25)$ & $(23.70)$ & $(22.71)$ & $(23.64)$ & - \\
log(assets) & $-0.012^{* * *}$ & -0.007 & $-0.013^{* * *}$ & $-0.017^{* * *}$ & $-0.012^{* * *}$ \\
& $(-4.16)$ & $(-1.60)$ & $(-2.94)$ & $(-3.71)$ & $(-4.02)$ \\
q & $-0.007^{* *}$ & -0.004 & -0.004 & -0.004 & $-0.006^{* *}$ \\
& $(-2.52)$ & $(-1.08)$ & $(-1.13)$ & $(-0.87)$ & $(-2.31)$ \\
Firm fixed effects & $\mathrm{Y}$ & $\mathrm{Y}$ & $\mathrm{Y}$ & $\mathrm{Y}$ & $\mathrm{Y}$ \\
Year fixed effects & $\mathrm{Y}$ & $\mathrm{Y}$ & $\mathrm{Y}$ & $\mathrm{Y}$ & $\mathrm{Y}$ \\
$\mathrm{R}$ & 0.119 & 0.204 & 0.201 & 0.205 & 0.115 \\
$\mathrm{~N}$ & 66768 & 43807 & 38505 & 37371 & 66768 \\
\hline \hline
\end{tabular}


Panel B: Excess return as performance measure

\begin{tabular}{lccccc}
\hline \hline \multirow{2}{*}{ Dep. Var. - Model } & \multicolumn{5}{c}{ CEO Turnover [t] $\{0,1\}-$ OLS } \\
\cline { 2 - 5 } Sample: & \multicolumn{5}{c}{$1926-2011$} \\
Power proxy: & 1926-2011 & $1960-2011$ & \multicolumn{2}{c}{ Tenure $\geq 4$} & $1926-2011$ \\
\cline { 2 - 6 } & Low indep. & Chair duality & High ROA & High return & Long tenure \\
\cline { 2 - 6 } & $-0.484^{* * *}$ & $-0.746^{* * *}$ & $-0.525^{* * *}$ & $-1.149^{* * *}$ & $-0.496^{* * *}$ \\
\hline Excess Ret [t] & $(-10.22)$ & $(-9.16)$ & $(-7.96)$ & $(-17.85)$ & $(-10.60)$ \\
Excess Ret [t] $\times$ Power & 0.095 & $0.342^{* * *}$ & $0.987^{* * *}$ & $3.074^{* * *}$ & $0.151^{* *}$ \\
& $(1.20)$ & $(3.92)$ & $(9.62)$ & $(28.45)$ & $(1.98)$ \\
Excess Ret [t-1] & $-0.383^{* * *}$ & $-0.340^{* * *}$ & $-0.548^{* * *}$ & $-0.349^{* * *}$ & $-0.267^{* * *}$ \\
& $(-8.80)$ & $(-4.30)$ & $(-8.93)$ & $(-5.49)$ & $(-6.39)$ \\
Excess Ret [t-1] $\times$ Power & $0.234^{* * *}$ & 0.048 & $1.037^{* * *}$ & 0.159 & $-0.192^{* * *}$ \\
& $(3.33)$ & $(0.56)$ & $(10.08)$ & $(1.46)$ & $(-2.65)$ \\
Power & -0.007 & $-0.207^{* * *}$ & $-0.120^{* * *}$ & $-0.074^{* * *}$ & $0.066^{* * *}$ \\
& $(-1.46)$ & $(-37.72)$ & $(-12.63)$ & $(-8.29)$ & $(18.99)$ \\
CEO tenure & $0.007^{* * *}$ & $0.011^{* * *}$ & $0.012^{* * *}$ & $0.014^{* * *}$ & - \\
& $(22.75)$ & $(24.30)$ & $(22.99)$ & $(23.79)$ & - \\
log(assets) & $-0.013^{* * *}$ & $-0.009^{* *}$ & $-0.015^{* * *}$ & $-0.017 * * *$ & $-0.012^{* * *}$ \\
& $(-4.83)$ & $(-2.36)$ & $(-3.32)$ & $(-3.92)$ & $(-4.48)$ \\
$\mathrm{q}$ & -0.000 & 0.004 & 0.001 & -0.002 & -0.000 \\
& $(-0.15)$ & $(1.32)$ & $(0.31)$ & $(-0.48)$ & $(-0.11)$ \\
Firm fixed effects & $\mathrm{Y}$ & $\mathrm{Y}$ & $\mathrm{Y}$ & $\mathrm{Y}$ & $\mathrm{Y}$ \\
Year fixed effects & $\mathrm{Y}$ & $\mathrm{Y}$ & $\mathrm{Y}$ & $\mathrm{Y}$ & $\mathrm{Y}$ \\
$\mathrm{R}{ }^{2}$ & 0.118 & 0.198 & 0.195 & 0.217 & 0.115 \\
$\mathrm{~N}$ & 79422 & 53792 & 42878 & 41756 & 80809 \\
\hline \hline
\end{tabular}




\section{Table 8: Abnormal stock returns around death- and health-driven CEO turnover}

This table examines cumulative abnormal returns from two days before to two days after the announcement of CEO turnovers due to (sudden) death and serious health issues of the departing CEO for U.S. firms from 1950 to 2011, conditional on proxies for CEO power: An indicator for CEO tenure higher than 11 years, the third quartile (column 1); an indicator for whether the CEO is also the board chair (column 2); and an indicator for whether the departing CEO is a founder of the firm (column 3). Panel A reports for death and health-driven events, Panel B reports for deathdriven events, and Panel C reports estimates for sudden deaths only. To increase sample size, in this table only NASDAQ firms are included in addition to NYSE/AMEX firms. White standard errors are reported in parentheses. *, $* *$, and ${ }^{* * *}$ represent results significant at the 10,5 , and $1 \%$ levels, respectively.

\begin{tabular}{|c|c|c|c|}
\hline \multirow[t]{2}{*}{ Dep. Var. } & \multicolumn{3}{|c|}{ Cumulative abnormal returns $[-2,2]$} \\
\hline & $(1)$ & $(2)$ & (3) \\
\hline \multicolumn{4}{|c|}{ Panel A: Death and Health, 1950-2011 } \\
\hline Long tenure & $\begin{array}{c}0.027^{* *} \\
(2.05)\end{array}$ & $\begin{array}{l}- \\
-\end{array}$ & - \\
\hline Chair duality & - & $\begin{array}{c}0.031 * * * \\
(3.01)\end{array}$ & $\begin{array}{l}- \\
-\end{array}$ \\
\hline Founder & - & - & $\begin{array}{c}0.031 * * * \\
(2.62)\end{array}$ \\
\hline Constant & $\begin{array}{l}0.006 \\
(1.16)\end{array}$ & $\begin{array}{c}-0.013^{*} \\
(-1.66)\end{array}$ & $\begin{array}{l}-0.001 \\
(-0.12)\end{array}$ \\
\hline $\mathrm{R}^{2}$ & 0.015 & 0.023 & 0.025 \\
\hline $\mathrm{N}$ & 320 & 295 & 336 \\
\hline \multicolumn{4}{|c|}{ Panel B: Death only, 1950-2011 } \\
\hline Long tenure & $\begin{array}{c}0.039 * * * \\
(2.68)\end{array}$ & - & $\begin{array}{l}- \\
-\end{array}$ \\
\hline Chair duality & - & $\begin{array}{c}0.031^{* *} \\
(2.59)\end{array}$ & - \\
\hline Founder & $\begin{array}{l}- \\
-\end{array}$ & - & $\begin{array}{c}0.032 * * \\
(2.53)\end{array}$ \\
\hline Constant & $\begin{array}{l}0.002 \\
(0.42)\end{array}$ & $\begin{array}{l}-0.013 \\
(-1.35)\end{array}$ & $\begin{array}{l}-0.002 \\
(-0.41)\end{array}$ \\
\hline $\mathrm{R}^{2}$ & 0.037 & 0.022 & 0.030 \\
\hline $\mathrm{N}$ & 246 & 223 & 260 \\
\hline \multicolumn{4}{|c|}{ Panel B: Sudden death only, 1950-2011 } \\
\hline Long tenure & $\begin{array}{c}0.041^{* *} \\
(2.23)\end{array}$ & - & $\begin{array}{l}- \\
-\end{array}$ \\
\hline Chair duality & $\begin{array}{l}- \\
-\end{array}$ & $\begin{array}{l}0.020 \\
(1.33)\end{array}$ & - \\
\hline Founder & $\begin{array}{l}- \\
-\end{array}$ & - & $\begin{array}{c}0.035^{* *} \\
(2.02)\end{array}$ \\
\hline Constant & $\begin{array}{c}-0.013^{* *} \\
(-1.98)\end{array}$ & $\begin{array}{c}-0.021^{*} \\
(-1.73)\end{array}$ & $\begin{array}{c}-0.019 * * * \\
(-2.77)\end{array}$ \\
\hline $\mathrm{R}^{2}$ & 0.046 & 0.012 & 0.037 \\
\hline $\mathrm{N}$ & 142 & 123 & 149 \\
\hline
\end{tabular}

